\title{
1 When more is more: taking advantage of species diversity to move
}

\section{2 towards sustainable aquaculture}

4 Marielle Thomas ${ }^{1, *}$, Alain Pasquet ${ }^{1}$, Joël Aubin $^{2}$, Sarah Nahon ${ }^{3}$ and Thomas

$5 \quad$ Lecocq $^{1}$

${ }^{1}$ University of Lorraine, INRAE, URAFPA, Research Unit Animal and Functionalities of

Animal Products, University of Lorraine - INRAE, 2 Avenue de la Forêt de Haye, BP 172, 54505, Vandouvre-lès-Nancy, France

${ }^{2}$ UMR SAS, INRAE, Institut Agro, 35000 Rennes, France

${ }^{3}$ INRAE, Université de Pau et des Pays de l'Adour, E2S UPPA, UMR 1419, Nutrition, Métabolisme, Aquaculture, Saint Pée sur Nivelle, F-64310, France

\footnotetext{
*Author for correspondence (Tel.: +33 3727456 96; E-mail: marielle.thomas@univlorraine.fr).
}

\section{ABSTRACT}

Human population growth has increased demand for food products, which is expected to double in coming decades. Until recently, this demand has been met by expanding agricultural area and intensifying agrochemical-based monoculture of a few species. However, this development pathway has been criticised due to its negative impacts on the environment and other human activities. Therefore, new production practices are needed to meet human food requirements sustainably in the future. Herein, we assert that polyculture 
practices can ensure the transition of aquaculture towards sustainable development. We review traditional and recent polyculture practices (ponds, recirculated aquaculture systems, integrated multi-trophic aquaculture, aquaponics, integrated agriculture-aquaculture) to highlight how they improve aquaculture through the coexistence and interactions of species. This overview highlights the importance of species compatibility (i.e. species that can live in the same farming environment without detrimental interactions) and complementarity (i.e. complementary use of available resources and/or commensalism/mutualism) to achieve efficient and ethical aquaculture. Overall, polyculture combines aspects of productivity, environmental protection, resource sharing, and animal welfare. However, several challenges must be addressed to facilitate polyculture development across the world. We developed a four-step conceptual framework for designing innovative polyculture systems. This framework highlights the importance of $(i)$ using prospective approaches to consider which species to combine, (ii) performing integrated assessment of rearing environments to determine in which farming system a particular combination of species is the most relevant, (iii) developing new tools and strategies to facilitate polyculture system management, and (iv) implementing polyculture innovation for relevant stakeholders involved in aquaculture transitions.

Key words: aquaculture, sustainability, polyculture, species diversity, fish.

\section{CONTENTS}

\section{Introduction}

II. Polyculture approaches in aquaculture and their sustainability

(1) Species compatibility: the prerequisite of polyculture

(2) Species complementarity: the advantages of polyculture 
(a) Basic complementarity

(b) Enhanced complementarity based on trophic interactions

(c) Enhanced complementarity based on commensalism or mutualism

(3) How polyculture can become more sustainable

III. Limits of polyculture approaches and future developments

(1) To broaden and reconsider the vision of species diversity

(a) The components of biodiversity to consider

(b) Use of prospective approaches

(2) Understanding the big picture: advocating for integrated assessment of polyculture systems

(3) Developing new tools and strategies for managing polyculture systems

(4) Relevant considerations for implementing innovative approaches

IV. Conclusions

V. Acknowledgements

VI. References

\section{INTRODUCTION}

Since the 1950s, humankind has experienced its largest demographic increase. This increase has accelerated demand for food products, which is expected to double in coming decades (Foley et al., 2011)., Expanding agricultural land has been a solution to meet this unprecedented need, even though it implies competing with other land uses such as urban development and tourism, or destroying natural habitats. In the framework of the Green Revolution, agricultural intensification has been regarded as the main solution to decrease the need for new agricultural land. In this context, intensive systems were developed to farm a few highly productive species, usually in monoculture, with heavy use of agrochemical inputs 
(Robertson \& Swinton, 2005). However, these solutions have resulted in environmental problems such as biodiversity losses and soil/water degradation, which ultimately decrease agroecosystem yields in the medium or long term (Bennett et al., 2012; Isbell et al., 2017). Therefore, a new paradigm has been created: the growing demand for food products must be met in a sustainable way (see Table 1 for a glossary of terms). This requires drastically decreasing the environmental footprint of agriculture while also promoting socio-economic goals with employment for local communities, profit sharing, quality of life, support of local cultures, animal welfare, and quality of products (Thomas et al., 2015; Jennings et al., 2016; Valenti et al., 2018). Like other sectors, aquaculture is at the heart of these concerns.

In the future, aquaculture will have a key role in ensuring human food security and nutrition, especially as wild fisheries fail to meet the demand for aquatic products (FAO, 2020). The contribution of aquaculture to total human-consumed aquatic products has increased from less than 5\% in 1970 to nearly 50\% in 2018 (FAO, 2020). Current aquaculture is dominated by inland production systems with 51.3 million $\mathrm{t}$ of aquatic products, while coastal and marine systems contribute 30.8 million t (FAO, 2020). Aquaculture production involves 622 reared species, which increased by 32\% from 2006 to 2018 (FAO, 2020). Although the volume of aquaculture production is dominated by a few species belonging to the finfish group, only 27 species comprised over $90 \%$ of total finfish production in 2018. Finfish species are reared mainly in freshwater environments, such as in earthen ponds (e.g. traditional rice-fish culture systems in Asia), raceways, tanks, pens, and cages (FAO, 2020). By contrast, other widely produced species groups, especially crustaceans and molluscs, are reared mainly in marine and coastal aquaculture.

The development of aquaculture has experienced the same problems as terrestrial agriculture because of its intensification and land needs. It increasingly competes for natural resources (i.e. water, energy, and food) with other human activities (urban or tourism development) 
(Bostock et al., 2010; Boyd et al., 2020). It also contributes to habitat destruction, loss of biodiversity, water-quality degradation, overfishing of wild fish used as feed for farmed species, biological invasions, and genetic introgression from farmed stocks to wild local fauna (Beardmore, Mair \& Lewis, 1997; GESAMP, 2008; Lorenzen, Beveridge \& Mangel, 2012; Martinez-Porchas \& Martinez-Cordova, 2012; Christou et al., 2013; Diana et al., 2013; Jennings et al., 2016; Gozlan, 2017). Nevertheless, aquatic monoculture based on everincreasing intensification is considered as a major contributor to future food supplies, as reported for shrimp farms in Asia (Boyd et al., 2017; Engle et al., 2017). Aquatic monoculture production uses cages, ponds, or recirculated aquaculture systems (RASs) to produce a single species. The species farmed often have high commercial value and require massive amounts of formulated feed based on fish meal and oil (FAO, 2020), which have major negative environmental impacts (Tacon et al., 2010; Cashion et al., 2017; Meideros, Aubin \& Camargo, 2017). These negative impacts are further reinforced by the large amounts of solid effluents (faeces, feed wastes) and dissolved nutrients (waste products) discharged by monocultures, which contribute to eutrophication of wild aquatic ecosystems. Intensively fed monoculture can also be criticised from human food security and economic viewpoints, as it has $(i)$ lower viability and ability to withstand competition and pest attacks (e.g. Dahlberg, 1979), and (ii) a low potential to adapt to changes in environmental and economic contexts or to consumer expectations (Medeiros et al., 2017). Because of these alarming observations, development of sustainable aquaculture should draw lessons from terrestrial agronomy, in which monoculture is increasingly mistrusted, especially as its performance decreases over time (Bennett et al., 2012; Isbell et al., 2017). Consequently, future development of aquaculture cannot rely entirely on intensively fed monoculture.

Although no operational and/or scientific consensus exists about which option(s) can result in sustainable aquaculture, an overview of current practices suggests that some solutions already 
exist (Bunting, 2013). Current aquaculture systems differ along gradients of intensification and impacts on the environment (e.g. water/space needed for production, human modification of rearing environments). Their dependence on external inputs and impacts on natural resources vary widely among production systems and biophysical/economic contexts (Naylor et al., 2009; Bostock et al., 2010; Jennings et al., 2016; Boyd et al., 2020). Among practices that are alternatives to monoculture, polyculture could be an opportunity to develop more sustainable livestock systems by benefiting from the coexistence of taxa and/or interactions among species (Milstein et al., 2006; Rahman et al., 2006, 2008; Altieri, Koohafkan \& Nicholls, 2014). Species diversity, based on interspecific compatibility or complementarity in a farming environment could improve resource use as well as the use of one species' waste by another. Using species diversity to break the monoculture paradigm is currently considered a key agroecological principle for redesigning systems (Gaba et al., 2015; Altieri, Nicholls \& Montalba, 2017). In terrestrial environments, animal species diversity has been shown to increase resilience to economic disturbances, decrease animal sensitivity to parasitism (Sabatier et al., 2015; Dumont et al., 2020), and increase sustainability in food and nutrition security (Frison, Cherfas \& Hodgkin, 2011). In this review, we assess how polyculture can facilitate the transition of agriculture towards sustainable development. Polyculture has a wide variety of configurations, all of which may be relevant options to facilitate this transition.

However, an overview of polyculture practices and critical assessment of their advantages and disadvantages is still lacking. Therefore, herein we review the variety of polyculture approaches in aquaculture at several spatial scales and consider their sustainability. We then use this information to identify current obstacles and develop both conceptual and research prospects that could facilitate the development of sustainable aquaculture. 

SUSTAINABILITY

\section{(1) Species compatibility: the prerequisite of polyculture}

152

153

154

155

156

157

158

159

160

161

162

163

164

165

166

167

All polyculture approaches require compatibility among co-farmed taxa to limit interspecific competition as much as possible, thus ensuring animal welfare and ultimately the performance of the farming system. This species compatibility is either intrinsic or is ensured by management practices (Table 2). An example of intrinsic compatibility is the polyculture of benthic and pelagic species, which minimises interspecific competition (Henne, Romero \& Carmichael, 2007; Kozlowski et al., 2014). Ad libitum feeding, which avoids interspecific competition in the farmed stock (Sonay \& Bascinar, 2017) is an example of a management practice that promotes compatibility. Another management practice consists of installing devices to organise the spatial distribution of species to avoid detrimental interactions (e.g. Wang et al., 2015) such as cage-cum-pond or sequential polyculture (Martinez-Porchas et al. (2010). Species compatibility depends on (i) the rearing environment by considering resource availability that encourages the expression of species-specific behaviour and (ii) the speciesspecific growth rate and individual age, because species can be compatible initially but experience detrimental interactions later due to different growth rates, resulting in predation risk or trophic competition. Compatibility among species is no longer ensured once species develop detrimental interactions (e.g. aggressiveness, predation) or compete for a resource (food, space, shelter). This indicates that it is crucial to assess species compatibility and how it changes throughout the farming period. Overall, polyculture based on species compatibility allows farmed products to be diversified without necessarily aiming for direct environmental benefits (Barrington, Chopin \& Robinson, 2009).

\section{(2) Species complementarity: the advantages of polyculture}


174 Compatible species ( $i$ ) use available resources in a complementary way (i.e. species-specific

resource use), (ii) are connected to each other via trophic flows, and/or (iii) develop beneficial interactions such as commensalism or mutualism. Species experience these processes in a variety of farming environments, which corresponds to a gradient from 'basic complementarity' to 'enhanced complementarity'.

\section{(a) Basic complementarity}

Basic complementarity combines compatible species to use all available resources (i.e. food, space, shelter) in a given farming environment (Table 2). One example is traditional Chinese polyculture of carp (Fig. 1A), which illustrates a case of 'multitrophic polyculture' (MartinezPorchas et al., 2010). It combines several species from different trophic niches into a rearing system that mimics a simplified natural ecosystem (Hao-Ren, 1982). It usually includes grass carp (Ctenopharyngodon idella) that feed on terrestrial and aquatic macrophytes, bighead carp (Hypophthalmichthys nobilis) that feed on zooplankton, silver carp (Hypophthalmichthys molitrix) that feed on phytoplankton, and common carp (Cyprinus carpio) that feed on mud detritus and invertebrates (Milstein, 1992). Basic complementarity is also effective for species that use the same trophic resource in different spatial niches (Kozlowski et al., 2014; Thomas et al., 2020; Fig. 1B). This is known as 'monotrophic polyculture', and is sometimes considered less favourable for ecological balance than 'multitrophic polyculture' (MartinezPorchas et al., 2010). These combinations of compatible species may involve additional processes besides those in basic complementarity (see below).

\section{(b) Enhanced complementarity based on trophic interactions}

Enhanced complementarity based on trophic interactions uses the concept of 'integrated farming', in which waste from one production subsystem can serve as a food resource for 
another subsystem, thus increasing the efficiency of the entire system (Edwards, Pullin \& Gartner, 1988). In the late 20th century, implementing integrated farming in aquaculture resulted in the development of integrated multi-trophic aquaculture (IMTA) and integrated agriculture-aquaculture (IAA). In IMTA, trophic interactions are supported by water flows, for example by combining pellet-fed species (e.g. fish, shrimp) with species that extract particulate or dissolved organic matter (e.g. fish, echinoderms, molluscs) and species that extract inorganic matter (e.g. micro-/macro-algae, macrophytes) (Troell et al., 2009; Fig. 2A). Probably due to a lack of a precise definition, IMTA encompasses different approaches (Neori et al., 2004; Li et al., 2019; Table 2), that can be used on land or in coastal marine environments, or offshore for the most recent aquaculture systems, thus opening up new perspectives for food production (Buck et al., 2018). IMTA can also refer to aquaponics. In aquaponics, trophic complementarity between animal and plant species is also supported by water flows, but in soil-less systems. Aquaponics is based on establishing natural biological cycles to minimise the use of non-renewable resources (Tyson, Treadwell \& Simonne, 2011), and results in a combination of fish, plants, and microorganisms (Goddek et al., 2015). It thus recovers what is considered waste from fish production (e.g. nitrate) as an essential input for crop production (Love et al., 2014; Jaeger et al., 2019). In IAA systems, species complementarity can be achieved by connecting terrestrial and aquatic production units (FAO, 2019; Fig. 2B). This promotes agricultural diversification in which the aquaculture component generally involves semi-intensive farming of low-value herbivorous or omnivorous fish (e.g. carp, tilapia), combined with land-based animal and/or plant production (Prein, 2002; Pant, Demaine \& Edwards, 2004). IAA systems combine fish mainly with rice, pigs, or poultry (Zajdband, 2011). More complex IAA systems are used in Southeast Asia, however, where fish are combined with rice as a main crop, fruits and vegetables as secondary 
crops, and terrestrial animals such as grass-fed cattle and scavenging pigs or poultry

(Devendra \& Thomas, 2002; Nhan et al., 2007).

\section{(c) Enhanced complementarity based on commensalism or mutualism}

Polyculture can foster beneficial interactions among species. For example, a commensal relationship between rohu (Labeo rohita) and common carp (Cyprinus carpio), a popular fish polyculture in South Asia, is based on the ecological process of facilitation. In this polyculture, the foraging behaviour of carp benefits rohus by resuspending nutrients accumulated in the sediment into the water column (Fig. 3A). This results in bottom-up control of the food web, which significantly increases rohu production compared to that in monoculture farming (Rahman et al., 2006; Table 2). Polyculture can also provide interesting alternatives to drug treatments by promoting direct biotic interactions. For example, using cleaner fish (e.g. ballan wrasse Labrus bergylta) to control sea lice in Atlantic salmon (Salmo salar) is a mutualistic interaction that is increasingly used in cage farms (Brooker et al., 2018; Fig. 3B).

\section{(3) How polyculture can become more sustainable}

More sustainable aquaculture must be resilient, productive, and environmentally friendly (Costa-Pierce \& Page, 2013), but it must also be culturally sensitive, ethical, socially just, economically viable, and technically appropriate (FAO, 1995). Moreover, there are growing concerns about fish welfare in aquaculture production, as shown in the new FishEthoBase database (Saraiva et al., 2019) that must be considered in future aquaculture development. Therefore, assessing the sustainability of polyculture requires considering the issues involved in aquatic farming. 
Species complementarity in polyculture contexts is an essential feature supported by agroecology and ecological aquaculture (Dumont et al., 2013; Costa-Pierce, 2015; Aubin et al., 2019). These approaches provide a valuable framework for reconciling productivity, environmental conservation, resource sharing, and animal welfare. Polyculture approaches promote synergies among species and/or compartments of the system (Little \& Edwards, 2003; Nhan et al., 2007; Bostock et al., 2010; Zajdband, 2011). They increase efficiency in the use of resources that are naturally present or supplied to the agricultural environment. In polyculture systems, the use of unexploited resources from primary culture activities by secondary culture activities is a potential strategy to create an ecologically balanced culture system that improves water quality, reduces the ecological footprint, and increases the supply of goods and services (Wang et al., 1998; Tian et al., 2001; Barrington et al., 2009; Buck et $a l ., 2018)$. These polyculture systems thus have good environmental and agronomic performance because they recycle nutrients (e.g. carbon, nitrogen, and phosphorus) into the biomass of farmed organisms (Chopin et al., 2001; Martinez-Porchas \& Martinez-Cordova, 2012; David, Proença \& Valenti, 2017a,b; Flickinger et al., 2019, 2020). The ability of organisms to recover and/or transform nutrients that would otherwise be wasted and become potential pollutants (bioremediation role) also reduces dependence on external inputs (Table 2). For example, aquaponics, which combines aquaculture and hydroponic farming, mitigates some of the disadvantages of each system by providing a food-production system with higher environmental sustainability than the two systems considered separately (Goddek et al., 2015). It also decreases pollution and the need for resources (Rakocy, 1989).

Polyculture approaches can also increase the resilience of farming systems (Dumont et al., 2020). Hypotheses about the influence of species diversity on enhanced system resilience are based mainly on the 'portfolio effect' (Figge, 2004; Volaire, Barkaoui \& Norton, 2014), in which communities with high species diversity are likely to contain complementary species 
that can adapt to changing environmental conditions. Moreover, farmed species diversity creates new income sources and decreases operational and financial risks that monoculture can have, as shown by IMTA (Knowler et al., 2019). Polyculture can also be an opportunity to produce certain species that may not be economically profitable when reared in monoculture (Stickney, 2013). This may be due to polyculture farming conditions that are more favourable to the growth of such species than those of monoculture. For example, body mass gains of Nile tilapia (Oreochromis niloticus) and African catfish (Clarias gariepinus) are higher when these fish are raised together rather than separately (Shoko et al., 2016). The economic benefits of polyculture are related directly to using the trophic complementarities of the farmed species to maximise use of all food resources available in the ecosystem (Milstein, 1992; Kumaresan et al., 2009; Troell et al., 2009).

Although several advantages of polyculture have been established, its financial return and economic performance remain poorly assessed (Edwards, 2015; Cunha et al., 2019).

Economic benefits of polyculture systems can be increased, however, by selecting species with high added value (e.g. crab, crayfish, shrimp) or those that produce over longer periods (e.g. building dikes in rice fields to allow aquatic species to grow, even during the rice harvest or dry season) (Li et al., 2018). Through their trophic behaviour, some species improve economic performance directly by decreasing the time required for cleaning operations (Table 2) or indirectly by limiting fouling on nets, and improving water circulation and the fish environment (Mungkung et al., 2013). Moreover, species such as sea cucumbers (Holothuroidea) are able to consume fouling debris in salmon net pens and thus transform it into a marketable product (i.e. invertebrate biomass; Nelson, MacDonald \& Robinson, 2012). This case illustrates how polyculture can function as an alternative to cleaning operations (Ahlgren, 1998). 
Besides having better performance, resilience, and economic benefits, polyculture can also stress fish less than monoculture by improving animal welfare, either directly due to the combination of species (Papoutsoglou et al., 2001) or indirectly due to the need for fewer maintenance operations (Table 2). This can increase social acceptance of the species produced. Generally, all initiatives that improve the welfare of farmed animals must be viewed from the perspective of social sustainability, even though consumer expectations of animal welfare vary greatly among countries (Feucht \& Zander, 2015; Alexander et al., 2016). Polyculture could also change the societal perception of aquaculture [e.g. see Alexander et al. (2016) for IMTA].

\section{LIMITS OF POLYCULTURE APPROACHES AND FUTURE DEVELOPMENTS}

Although the different polyculture approaches can ensure more sustainable aquaculture production, many challenges remain to ensure their development. Polyculture is intrinsically more complex than monoculture because it requires a wider range of specific knowledge and skills to meet physiological and behavioural requirements of all farmed species and ethical standards and regulations for aquaculture systems. Creating a successful polyculture system implies that farmers understand and control, as much as possible, the system's eco-biological processes and their spatial and temporal dynamics. This includes flows of mass, nutrients, and energy that are produced, used, and transformed between biotic and abiotic compartments.

Doing so requires careful and ongoing observations of the polyculture system, with management adapted to each context and able continuously to readjust (Nhan et al., 2006;

Dumont et al., 2013). Developing agro-ecological practices could be promoted to achieve this kind of management (Aubin et al., 2017), but farmers must also agree to adopt new practices. Providing additional evidence about benefits of polyculture could help convince them to do so (Alexander et al., 2016). Obtaining such evidence requires promoting training as well as 
multi-disciplinary and participatory research, as polyculture approaches involve changing the nature of work. Based on these considerations and current developments in polyculture approaches, we present four fundamental steps to move towards more sustainable aquaculture (Fig. 4): (i) consider which species to combine, (ii) identify in which farming systems they will function best, (iii) develop management methods and (iv) implement these new approaches.

\section{(1) To broaden and reconsider the vision of species diversity}

Efficient polyculture implies designing species combinations that promote complementarity, which first requires considering biodiversity in farming systems. Biodiversity includes species diversity, genetic diversity, species abundance and biomass, physical organisation of species in space and time as well as the underlying ecological processes such as nutrient cycles. In this context, the next step is to develop an efficient approach to design multi-species farming that considers all aspects of biodiversity.

\section{(a) The components of biodiversity to consider}

The combination of species in the farming environment includes both planned and associated biodiversity. Planned biodiversity represents the species that the farmer chooses to produce (Swift, Izac \& van Noordwijk, 2004). These species, which must be compatible or even better, complementary, respond and act differently depending on their traits and the polyculture contexts in which they are produced (Table 2). Species must be chosen carefully based on a variety of criteria, such as (i) their origin, favouring native species (e.g. MartinezPorchas \& Martinez-Cordova, 2012), (ii) their ecological functions (e.g. detritivorous species) (Cranford, Reid \& Robinson, 2013), (iii) their feeding needs, with preference given to taxa 
that do not require exploiting declining resources, such as anchovy stocks to produce fish meal (FAO, 2020), and (iv) their ecological niche, such as their location in the water column. Eco-biological processes in polyculture systems also involve the associated biodiversity which includes wild fish, plants, aquatic invertebrates, microorganisms and terrestrial animals. These species, which are intrinsic to farming systems rather than chosen by the farmer, are involved to differing degrees in the processes of systems. For example, Rahman et al. (2008) observed that bacteria, protozoa, phytoplankton, and zooplankton improved water quality, fish production, and natural food availability. Thus, the microbial compartment deserves greater focus, particularly for polyculture systems in confined spaces (ponds, RASs, aquaponics), where it appears to have a major influence. Similarly, associated biodiversity may include species that are sources of food (e.g. macrophytes, benthic macro-invertebrates), predators (e.g. fish-eating birds, otters), or competitors (e.g. invasive species) of farmed species. These are important aspects to consider for improving the welfare of farmed animals and farm production. The composition of the combination of species will also refer to their species traits and interactions. For example, for a given combination of species, several studies have shown that fish growth and system performance vary depending on stocking densities (e.g. Azim et al., 2002a; Shoko et al., 2016). Similarly, depending on the physiological stages of the species reared together, changing diets or differing growth rates may make certain species combinations incompatible over time due to predation. Moreover, combining species can trigger spillover of interspecific pathogens (Ibrahem et al., 2011). This risk is often related to the use of exotic species (Naylor, Williams \& Strong, 2001), which argues for using indigenous species to establish species combinations to be farmed in polyculture. This places a premium on assessing potential pathogens before designing the species combination. 
371 The choice of species in polyculture is an essential component of existing polycultures.

372 Nevertheless, to develop polyculture further, rule-based selection is not possible due to the

373 many potential species combinations, not all of which can be tested due to practical and ethical concerns. An alternative strategy is to address species diversity from a taxonomic and functional viewpoint by studying species functional traits (Violle et al., 2007; Gravel, Albouy \& Thuiller, 2016), as already initiated for terrestrial environments (Diaz \& Cabido, 2001; Gaba et al., 2015). This approach, based on functional ecology, is valuable for understanding ecological community structure and ecosystem functions; it can be supported by information from databases (e.g. Frimpong \& Angermeier, 2009; Froese \& Pauly, 2017; Lecocq et al., 2019) that compile behavioural, morphological, phenological, and physiological traits of fish species and with reference to their environmental characteristics. Using functional traits thus could help to identify suitable combinations of species and explicitly to target objectives for system sustainability, such as better or minimal use of limited trophic resources, improved animal welfare (e.g. with integrated health management), and environmental conservation (e.g. by using co-products as feed). The data currently available mainly concern fish and should be extended to other aquaculture species. This prospective approach offers the potential to consider new combinations of compatible and/or complementary species and the functions they perform in their environment that allow them to meet new environmental and socio-economic challenges.

(2) Understanding the big picture: advocating for integrated assessment of polyculture systems

In a second step, a central issue is to specify in which farming system a given combination of species is most appropriate for improving system sustainability, resource-use efficiency, and 
animal welfare. It is clear that farmers do not have the same degree of experience with emerging technologies such as IMTA or aquaponics (Love et al., 2014; Konig et al., 2016; Villarroel et al., 2016) as they do with ponds, which have been used for several millennia (Zhao, 1994). In general, polyculture systems interweave ecological compartments, interspecific relationships, trophic flows in environments modified to differing degrees and, in particular, socio-economic contexts (Martinez-Porchas \& Martinez-Cordova, 2012). We thus argue that a farming system can be matched best to a combination of species only through an integrated approach.

Before designing polyculture systems, the first consideration is to ensure that water quality meets the requirements of the farmed species. The main physico-chemical variables relevant to aquaculture are water temperature, salinity, levels of dissolved oxygen, nitrogen and phosphorus compounds, and organic matter, while avoiding the risk of chemical contamination (Lazartigues et al., 2013). The species' requirements partly determine the choice of sites for open-water polyculture systems. In RAS polyculture, these parameters are controlled as far as possible by equipment and management practices. Control can be more challenging due to dependent factors such as feed levels, which will be related to stocking density and dissolved oxygen levels (Boyd et al., 2020). Controlling water quality traditionally requires technical solutions such as thermoregulation, water exchange, aeration, mechanical technology, and biofiltration or biofloc technology (Martins et al., 2010; Hisano et al., 2019). However, polyculture systems can offset some of these control requirements via internal regulatory processes such as recycling of the nutrients in waste (Neori et al., 2004; Martinez-Porchas et al., 2010; Boyd et al., 2020).

Interactions among biotic and abiotic compartments must be addressed as a whole and not by studying each process in isolation. In this context, over-reductionist approaches have been criticised as an obstacle to understanding fully how such systems function (Zajdband, 2011). 
This is illustrated by highlighting that waste from one compartment can be an input for several other compartments. In IAA for example, ruminant manure can be used as fertiliser for pond aquaculture, terrestrial crops or grasslands, and fuel for households (Prein, 2002). This results in potential competition for their use as well as the need to identify trade-offs. A general view of the system allows multiple processes to be considered, such as metabolisation, storage, and loss, by considering the temporal availability and quality of materials, nutrients and/or energy exchanged between compartments (e.g. Chary et al., 2020). One objective is to obtain the best possible synchronisation between what is produced and what is used in a given polyculture system. In IMTA systems, this is based in part on the purification efficiency of detritus feeders and primary producers, although IMTA systems with low yields, as observed in open-sea IMTA, may be called into question (Chary et al., 2020).

Polyculture systems can minimise environmental impacts of farming effluents, particularly nitrogen, phosphorus, and organic waste. Sedimentation and denitrification processes and, to a smaller extent, assimilation and metabolism of different species in the rearing environment (reared organisms, periphyton, or macrophytes) contribute to the mitigation effect of polyculture systems. This effect has been shown for nitrogen (e.g. David et al., 2017a) and pesticides from agricultural watersheds of polyculture ponds (Gaillard et al., 2016). These positive externalities, classified as ecosystem services of remediation, have been observed in many polyculture systems (Martinez-Porchas et al., 2010).

Overall, an integrated approach must consider both wanted and unwanted transfers among compartments that could influence functional processes of the entire system. In the relationships between the farming system and species combination, practices are also major drivers of system functioning. For example, the use of artificial feed benefits pond aquaculture in two ways (Milstein, 1992; Rahman et al., 2006): (i) directly, with feed 
consumption maximising synergistic relationships and minimising antagonistic relationships between farmed fish, and (ii) indirectly, through decomposition, which provides nutrients that initiate bottom-up control by supporting phytoplankton and zooplankton that feed filterfeeding organisms. Another option is to add substrates into ponds (Azim et al., 2002b; Crab et $a l ., 2007)$. This practice improves water quality by promoting the growth of periphyton, which converts organic waste into a potential food source for certain species reared in polyculture. These substrates also function as a refuge against predators or as reproduction areas.

\section{(3) Developing new tools and strategies for managing polyculture systems}

A third step for more sustainable aquaculture requires developing specific tools and new approaches to help manage the intrinsic complexity of polyculture systems. Thus, new technologies based on precision farming, using sensors, mathematical models, artificial intelligence, and information technology could help acquire and process information from animal-production systems and to improve knowledge about, practices in, and ultimately the overall functioning of these systems (Føre et al., 2018). These technologies could supplement modelling tools that currently exist or are under development (Ferreira, Saurel \& Ferreira, 2012; Ren et al., 2012), which are especially useful for complex systems (Reid et al., 2019).

Modelling would help design and set the size of the compartments of polyculture systems and consider the interactions (e.g. nature, amplitude, frequency) among them. For example, the Ecopath with Ecosim model (Christensen \& Pauly, 1992), a key ecosystem model for fisheries, has been used to model polyculture systems (Zhou, Dong \& Wang, 2015; Feng et al., 2017; Gamito et al., in press). Other models have been developed to increase understanding of the complex interactions in aquaculture and other human activities by considering the carrying capacity of the water environment (Rawson et al., 2002), based on 
extractive and fed aquaculture case studies. Real-time data acquisition and modelling tools require further development and use to understand and predict better the functioning of biotic and abiotic compartments of aquaculture systems. Biological tools can also be used to place polyculture approaches on a path that combines efficiency and sustainability. Thus, the choice of species can be based in part on their capacity to adapt to fluctuating feed availability and quality or climate change, which requires working on selection programs that consider genotype $\times$ environment interactions (Dumont et al., 2014). This choice may require considering intraspecific differences among populations of farmed species because they can influence the efficiency and sustainability of animal production (Toomey, Fontaine \& Lecocq, 2020). Research on epigenetic markers will also be relevant to developing a better understanding of the adaptive processes of species in variable polyculture contexts (Dumont et al., 2014). Microbiota engineering is another way to maintain or strengthen the immune function of organisms or simply to promote the growth of animals (Boyd et al., 2020). In this context, the use of functional ingredients such as prebiotics or probiotics, which until now have been used mainly in monoculture, could be adapted to future polyculture given the high diversity of taxonomic groups and thus the risk of pathogen transmission. Beyond these tools, the use of sustainability indicators (Valenti et al., 2018) and evaluation of ecosystem services (CICES, 2018) should be generalised and used to evaluate polyculture systems and help to meet future challenges (Willot et al., 2019).

\section{(4) Relevant considerations for implementing innovative approaches}

In a fourth, simultaneous step, new sustainable polyculture approaches can advance only with the support of all stakeholders, such as farmers, consumers, legislators, or social organisations (Blayac et al., 2014). Stakeholders' expectations should be considered carefully throughout the four steps. Fish farmers must consider consumer expectations when choosing which 
species to farm. For example, some carp species commonly farmed in Asia (e.g. Cyprinus carpio, Ctenopharyngodon idella, Hypophthalmichthys molitrix, Hypophthalmichthys nobilis) are poor candidates due to a lack of acceptance and market price in Europe (Barcellos et al., 2012). Consequently, one priority for researchers and farmers is to focus on identifying alternative species that serve as compromises among stakeholder expectations (Thomas et al., 2015). It is challenging to consider multiple aspects related to $(i)$ production (e.g. growth rate, yield, survival), (ii) environment (e.g. input dependence, environmental conservation), (iii) economic performance (e.g. cost effectiveness), (iv) product quality (i.e. hygienic, nutritional, health, sensorial, and technological components), and (v) ethical aspects (e.g. animal welfare, social acceptance).

Many aquaculture studies have indicated that solutions often involve the use of non-native species (e.g. tilapia farming is practiced around the world), while others highlight potential risks of non-native species (e.g. Lin, Gao \& Zhan, 2015). Consequently, decision-support tools have been developed specifically for potentially invasive aquatic species based on their biogeographic and historical characteristics and biological and ecological interactions (e.g. Copp et al., 2016), considering the risk of escape as a function of characteristics of the rearing system (e.g. outdoors or indoors). Finally, more evidence from new production practices must be provided to promote their adoption and widespread use, without ignoring the economic and intellectual efforts of animal farmers.

\section{CONCLUSIONS}

(1) It is essential to ensure sustainable development of aquaculture in economic, social, and environmental terms. Current aquaculture practices are very diverse. However, there is no operational and/or scientific consensus about which option(s) should be promoted to achieve greater sustainability. 
(2) Among aquaculture practices, polyculture approaches can ensure more sustainable production than monoculture. An overview of traditional and recent polyculture approaches highlights how they improve environmental and socio-economic sustainability of aquaculture. The processes involved are based on farmed species diversity that combines multiple functional groups.

(3) Polyculture requires considering species compatibility and complementarity. Species compatibility is a prerequisite of polyculture. It involves species that can share the same farming environment without detrimental interactions. Species can be compatible naturally (intrinsic compatibility) or through management practices. Polyculture can be further improved by $(i)$ mixing species that exploit different available resources, which includes food, space and/or shelter (i.e. basic complementarity), or (ii) using co-products in integrated systems and/or by taking advantage of commensalism or mutualism (i.e. enhanced complementarity).

(4) Through agroecology and ecological aquaculture concepts, polyculture can reconcile productivity, environmental conservation, resource sharing, and animal welfare. First, efficient polyculture systems promote synergies among species and/or compartments to achieve optimal use of all resources and decrease the ecological footprint. Second, polyculture can increase the resilience of farming systems based on species diversity adapted to different environmental conditions. Third, it can produce species that would be unprofitable in monoculture or beneficial species in relation to their trophic behaviour (alternatives to cleaning operations). Fourth, polyculture can increase social acceptance of the species produced when it improves animal welfare. However, polyculture implies that farmers understand and control a complex system with spatial and temporal dynamics of ecobiological processes. 
544 (5) We outline a four-step conceptual framework for implementing polyculture in the

545 development of an aquaculture that can reconcile productivity, animal welfare, and

546 environmental aspects, while seeking to be socially just, economically viable, and technically

547 appropriate. The first step consists of defining which species to combine using a prospective

548 approach based on their functional traits. The second step aims to select the appropriate

549 farming system using an integrated approach to consider relationships among all

550 compartments in space and time, as well as practices that can influence functional processes.

551 The third step requires developing specific tools (precision farming, modelling, biological

552 tools) to manage the complexity of polyculture systems. Finally, the fourth step focuses on

553 implementing the new approaches, by considering the multiple expectations of stakeholders.

554 (6) Several scientific challenges remain for understanding and controlling ecological

555 interactions in complex farming systems. We call for further research that combines

556 modelling, experiments, technological development and in-field analyses of existing practices

557 to design efficient polyculture practices for the future.

558

559 V. ACKNOWLEDGEMENTS

560 This study was supported by the Metaprogram EcoSerV2 of the French National Institute for

561 Agronomic Research (INRAE) and the research program SEPURE through the European

562 Fund for Maritime Affairs and Fisheries (FEAMP). We thank the anonymous reviewers for

563 their insightful comments.

564

565 VI. REFERENCES

566 AghuZbeni, S. H. H., HajirezAeE, S. \& Khara, H. (2016). Polyculture of western white

567 shrimp, Litopenaeus vannamei Boone, 1931 with Grey mullet, Mugil cephalus Linnaeus, 

2988.

570

AhLGREN, M. O. (1998). Consumption and assimilation of salmon net pen fouling debris by the red sea cucumber Parastichopus californicus: implications for polyculture. Journal of World Aquaculture Society 29, 133-139.

Alexander, K. A., Angel, D., Freeman, S., Israel, D., Johansen, J., Kletou, D., Meland, M., Pecorino, D., Rebours, C., Rousou, M., Shorten, M. \& Potts, T. (2016). Improving sustainability of aquaculture in Europe: Stakeholder dialogues on Integrated Multi-Trophic Aquaculture (IMTA). Environmental Science and Policy 55, 96106.

Altieri, M. A. (1987). Agroecology: the scientific basis of alternative agriculture. Westview Press, Boulder.

Altieri, M. A., KoohafKan, P. \& Nicholls, C. (2014). Strengthening resilience of modern farming systems: a key prerequisite for sustainable agricultural production in an era of climate change. Third World Network Briefing, paper No. 70. www.twnside.org.sg

Altieri, M. A., NichOlls, C. I. \& MonTALBA, R. (2017). Technological approaches to sustainable agriculture at a crossroads: an agroecological perspective. Sustainability 9, 349. Arsenault, R. \& Owen-Smith, N. (2002). Facilitation versus competition in grazing herbivore assemblages. Oikos 97, 313-318.

Aubin, J., Callier, M., Rey-Valette, H., Mathé, C., Wilfart, A., Legendre, M., Slembrouck, J., Caruso, D., Chia, E., Masson, G., Blancheton, J. P., Ediwarman, Haryadi, J., Prihadi, T. H., de Matos Casaca, J., TAmassia, S. T. J., ET al. (2019). Implementing ecological intensification in fish farming: definition and principles from contrasting experiences. Reviews in Aquaculture 11, 149-176. 
Aubin, J., Robin, J., Wezel, A. \& Thomas, M. (2017). Agroecological management in fish pond systems. In Agroecological Practices for Sustainable Agriculture: Principles, Applications, and Making the Transition (eds A. WEZEL), pp. 355-394. World Scientific Publishing, Europe.

Azim, M. E., Verdegem, M. C. J., Rahman, M. M., Wahab, M. A., van Dam, A. A. \& BEVERIDGE, M. C. M. (2002a). Evaluation of polyculture of Indian major carps in periphyton-based ponds. Aquaculture 213, 131-149.

Azim, M. E., Wahab, M. A., Verdegem, M. C. J., van Dam, A. A., van RooiJ, J. M. \& BEVERIDGE, M. C. M. (2002b). The effects of artificial substrates on freshwater pond productivity and water quality and the implications for periphyton-based aquaculture. Aquatic Living Resources 15, 231-241.

Barcellos, L. J. G., Quevedo, R. M., Kreutz, L. C., Ritter, F., Pandolfo, A., Hemkemeier, M. \& Colla, L. (2012). Comparative analysis of different fish polyculture systems. Journal of the World Aquaculture Society 43, 778-789.

BARRINGTON, K., CHOPIN, T. \& RobInSON, S. (2009). Integrated multi-trophic aquaculture (IMTA) in marine temperature waters. In FAO Fisheries and Aquaculture Technical Paper (eds D. Soto), pp. 7-46. 529.

BeARdmore, J. A., MaIR, G. C. \& LeWIS, R. I. (1997). Biodiversity in aquatic systems in relation to aquaculture. Aquaculture Research 28, 829-839.

Bennett, A. J., Bending, G. D., Chandler, D., Hilton, S. \& Mills, P. (2012). Meeting the demand for crop production: the challenge of yield decline in crops grown in short rotations. Biological Reviews 87, 52-71.

Blayac, T., Mathe, S., Rey-Valette, H. \& Fontaine, P. (2014). Perceptions of the services provided by pond fish farming in Lorraine (France). Ecological Economics 108, $115-123$. 
Boock, M. V., Marques, H. A., Mallasem, M., Barros, H. P., Moraes-Valenti, P. \& VALENTI, W. C. (2016). Effects of prawn stocking density and feeding management on rice-prawn culture. Aquaculture 451, 480-487.

Bostock, J., McAndrew, B., Richards, R., Jauncey, K., Telfer, T., Lorenzen, K., LitTle, D., Ross, L., HANDisyde, N., GATwARD, I. \& CoRnER, R. (2010). Aquaculture: global status and trends. Philosophical Transactions of the Royal Society B 365, 28972912.

Boyd, C., McNevin, A., Racine, P., Paungkaew, D., Viriyatum, R., Tinh, H. Q. \& Engle, C. R. (2017). Resource use of shrimp Litopenaeus vannamei and Penaeus monodon production in Thailand and Vietnam. Journal of the World Aquaculture Society 48, 201226.

Boyd, C. E., D’Abramo, L. R., Glencross, B. D., Huyben, D. C., Juarez, L. M., Lockwood, G. S., McNevin, A. A., Tacon, A. G. J., Teletchea, F., Tomasso JR, J. R., TUCKeR, C. S. \& VALENTI, W. C. (2020). Achieving sustainable aquaculture: Historical and current perspectives and future needs and challenges. Journal of the World Aquaculture Society 51, 578-633.

Brooker, A. J., Papadopoulou, A., Gutierrez, C., Rey, S., Davie, A. \& Migaud, H. (2018). Sustainable production and use of cleaner fish for the biological control of sea lice: recent advances and current challenges. Veterinary Record 183, 383.

Buck, B. H., Troell, M. F., Krause, G., Angel, D. L., Grote, B., \& Chopin, T. (2018). State of the art and challenges for offshore integrated multi-trophic aquaculture (IMTA). Frontiers in Marine Science 5, 1-22.

Bunting, S. W. (2013). Principles of sustainable aquaculture: promoting social, Economic and environmental resilience. Routledge, Oxford. 
Cashion, T., Le Manach, F., Zeller, D. \& Pauly, D. (2017). Most fish destined for fishmeal production are food-grade fish. Fish and Fisheries 18, 837-844.

Chary, K., Aubin, J., Sadoul, B., Fiandrino, A., Coves, D. \& Callier, M. D. (2020). Integrated multi-trophic aquaculture of red drum (Sciaenops ocellatus) and sea cucumber (Holothuria scabra): assessing bioremediation and life-cycle impacts. Aquaculture 516, 734621.

Chopin, T., Buschmann, H., Halling, C., Troell, M., Kautsky, N., Neori, A., Kraemer, G. P., Zertuche-GonZÁlez, J. A., Yarish, C. \& Neefus, C. (2001). Integrating seaweeds into marine aquaculture systems: a key toward sustainability. Journal of Phycology 37, 975-986.

Chopin, T., Robinson, S., Troell, M., Neori, A., Buschmann, A. \& Fang, J. (2008). Multitrophic integration for sustainable marine aquaculture. In The Encyclopedia of Ecology, Ecological Engineering (eds S. JORGENSEN and B. D. FATH), pp. 2463-2475. Elsevier, Oxford 3.

Chopin, T, Troell, M., ReID, G. K., Knowler, D., Robinson, S. M. C., NeOri, A., Buschmann A. H. \& PANG, S. (2010). Integrated multi-trophic aquaculture, part 1. Global Aquaculture Advocate. https://www.aquaculturealliance.org/advocate/integrated-multi$\underline{\text { trophic-aquaculture-part-1/ }}$

Christensen, V. \& PAUly, D. (1992). ECOPATH II - A softwater for balancing steady-state ecosystem models and calculating network characteristics. Ecological Modelling 61, 169185.

Christou, P., Savin, R., Costa-Pierce, B. A., Misztal, I. \& Whitelaw, C. B. A. (2013). Sustainable Food Production. Springer New York, pp. 1896.

CICES (COMMON INTERNATIONAL CLASSIFICATION OF ECOSYSTEM SERVICES) (V5.1). (2018). Guidance of the application of the revised structure, pp. 53. 
Copp, G. H., Vilizzi, L., Tidbury, H., Stebbing, P. D., Tarkan, A. S., Miossec, L. \& GOULLETQueR, P. (2016). Development of a generic decision-support tool for identifying potentially invasive aquatic taxa: AS-ISK. Management of Biological Invasions 7, 343 350.

Costa-Pierce, B. A. (2015). Seven Principles of Ecological Aquaculture: A Guide for the Blue Revolution. Ecological Aquaculture Foundation, Biddeford, Maine, USA.

Costa-Pierce, B. A. \& PAge, G. G. (2013). Aquaculture, Sustainability, Science. In Sustainable Food Production (eds P. Christou, R. SAvin, B. A. CostA-Pierce, I. MiszTAL and C. B. A. Whitelaw), pp. 206-222. Springer New York.

Crab, R., Avnimelech, Y., Defoirdt, T., Bossier, P. \& Verstraete, W. (2007). Nitrogen removal techniques in aquaculture for a sustainable production. Aquaculture 270, 1-14.

Cranford, P. J., ReID, G. K. \& Robinson, S. M. C. (2013). Open water integrated multitrophic aquaculture: constraints on the effectiveness of mussels as an organic extractive component. Aquaculture Environment Interactions 4, 163-173.

Cunha, M. E., Quental-Ferreira, H., Parejo, A., Gamito, S., Ribeiro, L., Moreira, M., Monteiro, I., SoAres, F. \& PousÃo-FerreirA, P. (2019). Understanding the individual role of fish, oyster, phytoplankton and macroalgae in the ecology of integrated production in earthen ponds. Aquaculture 512, 734297.

DAHLBERG, K. A. (1979). Beyond the green revolution. The ecology and politics of global agricultural developments. Western Michigan University, Kalamazoo, pp. 256.

DAVID, F. S., ProençA, D. C. \& VAlENTI, W. C. (2017a). Nitrogen budget in integrated aquaculture systems with Nile tilapia and Amazon River prawn. Aquaculture International 25, 1733-1746.

David, F. S., ProençA, D. C. \& VAlenti, W. C. (2017b). Phosphorus budget in integrated multitrophic aquaculture systems with Nile Tilapia (Oreochromis niloticus) and Amazon 

$402-414$.

693

694

695

696

697

698

699

700

701

702

703

704

705

706

707

708

709

710

711

712

713

714

715

DevendRA, C. \& Thomas, D. (2002). Crop-animal interactions in mixed farming systems in Asia. Agricultural Systems 71, 27-40.

Dey, B. K., Dugassa, G. H., Hinzano, S. M. \& Bossier, P. (2020). Causative agent, diagnosis and management of white spot disease in shrimp: a review. Reviews in Aquaculture 12, 822-865.

Diana, J. S., Egna, H. S., Chopin, T., Peterson, M. S., CaO, L., Pomeroy, R., Verdegem, M., Slack, W. T., Bondad-Reantaso, M. G. \& Cabello, F. (2013). Responsible aquaculture in 2050: Valuing local conditions and human innovations will be key to success. BioScience 63, 255-262.

DiAZ, S. \& CABIDO, S. (2001). Vive la difference: plant functional diversity matters to ecosystem processes. Trends in Ecology and Evolution 16, 646-655.

Dumont, B., Fortun-Lamothe, L., Jouven, M., Thomas, M. \& Tichit, M. (2013). Prospects from agroecology and industrial ecology for animal production in the $21^{\text {st }}$ century. Animal 7, 1028-1043.

Dumont, B., GonzÁlez-Garcia, E., Thomas, M., Fortun-Lamothe, L., Ducrot, C., DourmaD, J. Y. \& TICHIT, M. (2014). Forty research issues for the redesign of animal production systems in the $21^{\text {st }}$ century. Animal 8, 1382-1393.

Dumont, B., Puillet, L., Martin, G., Savietto, D., Aubin, J., Ingrand, S., Niderkorn, V., STEINMETZ, L. \& THOMAS, M. (2020). Incorporating diversity into animal production systems can increase their performance and strengthen their resilience. Frontiers in Sustainable Food Systems 4, 109.

EDWARDS, P. (2015). Aquaculture environment interactions: Past, present and likely future trends. Aquaculture 447, 2-14. 
Edwards, P., Pullin, R. S. V. \& GARTNER, J.A. (1988). Research and education for the development of integrated crop-livestock-fish farming systems in the tropics. ICLARM Studies and Reviews, 16, pp. 53. International Center for Living Aquatic Resources Management, Manila, Philippines.

Engle, C. R., McNevin, A., Racine, P., Boyd, C. E., PAungkaew, D., ViRiyatum, R., Tinh, H.Q. \& MINH, H. N. (2017). Economics of sustainable intensification of aquaculture: evidence from shrimp farms in Vietnam and Thailand. Journal of the World Aquaculture Society 48, 227-239.

FAO (Food and Agriculture Organization of the United Nations) (1995). Code of conduct for responsible fisheries. FAO, Rome, 41 pp. http://www.fao.org/3/v9878e/v9878e00.htm

FAO (2019). Report of the special session on advancing integrated agriculture aquaculture through agroecology, Montpellier, France, 25 August 2018. FAO, Fisheries and Aquaculture Report, No. 1286. Rome. http://www.fao.org/3/ca7209en/ca7209en.pdf

FAO (2020). The state of World Fisheries and Aquaculture 2020. Sustainability in action. Rome. https://doi.org/10.4060/ca9229en

Feng, J., Tian, X. L., Dong, S. L., He, R. P., Zhang, K., Zhang, D. X. \& Zhang, Q. Q. (2017). Model-based analysis of the energy fluxes and trophic structure of a Portunus trituberculatus polyculture ecosystem. Aquaculture Environment Interactions 9, 479-490.

Ferreira, J. G., SAurel, C. \& Ferreira, J. M. (2012). Cultivation of gilthead bream in monoculture and integrated multi-trophic aquaculture. Analysis of production and environmental effects by means of the FARM model. Aquaculture 358-359, 23-34.

FEUCHT, Y. \& ZANDER, K. (2015). Of earth ponds, flow-through and closed recirculation systems - German consumers' understanding of sustainable aquaculture and its communication. Aquaculture 438, 151-158. 
FIGGE, F. (2004). Bio-folio: apply portfolio theory to biodiversity. Biodiversity and Conservation 13, 827-849.

Flickinger, D. L., Costa, G. A., Dantas, D. P., Moraes-Valenti, P. \& Valenti, W. (2019). The budget of nitrogen in the grow-out of the Amazon river prawn (Macrobrachium amazonicum Heller) and tambaqui (Colossoma macropomum Cuvier) farmed in monoculture and in integrated multitrophic aquaculture systems. Aquaculture Research 50, 3444-3461.

Flickinger, D. L., Dantas, D. P., Proença, D. C., David, F. S. \& Valenti, W. C. (2020). Phosphorus in the culture of the Amazon river prawn (Macrobrachium amazonicum) and tambaqui (Colossoma macropomum) farmed in monoculture and in integrated multitrophic systems. Journal of the World Aquaculture Society 51, 1002-1023.

Foley, J. A., Ramankutty, N., Brauman, K. A., Cassidy, E. S., Gerber, J. S., Johnston, M., Mueller, N. D., O’Connell, C., Ray, D. K., West, P. C., Balzer, C., Bennett, E. M., CARpenter, S. R., Hill, J., Monfreda, C., ET AL. (2011). Solutions for a cultivated planet. Nature 478, 337-342.

Fonseca, T., David, F. S., Ribeiro, F. A. S., Wainberg, A. A. \& Valenti, W. C. (2017). Technical and economic feasibility of integrating seahorse culture in shrimp/oyster farms. Aquaculture Research 48, 655-664.

Føre, M., Frank, K., Norton, T., Svenden, E., Alfredsen, J. A., Dempster, T., Eguiraum, H., Watson, W., Stahl, A., Sunde, L. M., Schellewad, C., Skøien, K. R., Alver, M. O. \& BERCKMANS, D. (2018). Precision fish farming: A new framework to improve production in aquaculture. Biosystems Engineering 173, 176-193.

Franchini, A. C., Costa, G. A., Pereira, S. A., Valenti, W. C. \& Moraes-Valenti, P. (2020). Improving production and diet assimilation in fish-prawn integrated aquaculture, using iliophagus species. Aquaculture 521, 735048. 
Frimpong, E. A. \& ANGERMEIER, P. L. (2009). Fish Traits: a database of ecological and lifehistory traits 239 of freshwater fishes of the United States. Fisheries 34, 487-495.

Frison, E. A, Cherfas, J. \& Hodgkin, A. (2011). Agricultural biodiversity is essential for a sustainable improvement in food and nutrition security. Sustainability 3, 238-253.

Froese, R. \& PAuly, D. (2017). FishBase. Available at: www.fishbase.org. (Accessed: 8th February 237 2018).

Gaba, S., Lescourret, F., Boudsocq, S., Enjalbert, J., Hinsinger, P., Journet, E. P., Navas, M. L., Wery, J., Louarn, G., Malezieux, E., Pelzer, E., Prudent, M. \& OZIER-LAFONTAINE, H. (2015). Multiple cropping systems as drivers for providing multiple ecosystem services: from concepts to design. Agron. Sustain. Development 35, $607-623$.

Gaillard, J., Thomas, M., Lazartigues, A., Bonnefille, B., Pallez, C., Dauchy, X., FEIDT, C. \& BANAS D. (2016). Potential of barrage fish ponds for the mitigation of pesticide pollution in streams. Environmental Science and Pollution Research 23, 23-35.

Gamito, S., Quental-Ferreira, H., Parejo, A., Aubin, J., Christensen, V. \& Cunha, M.E. (in press). Integrated multi-trophic aquaculture systems: energy transfers and food web organization in coastal earthen ponds. Aquaculture Environment Interactions.

GaO, X., Ke, C., Zhang, M., LI, X., Wu, F. \& LiU, Y. (2019). N and P budgets of Haliotis discus hanai, Apostichopus japonicas, and Sebastes schlegeli in a polyculture system. Aquaculture Research 50, 2398-2409.

GESAMP (2008). Assessment and communication of environmental risks in coastal aquaculture. Reports and studies GESAMP n76, FAO, Rome, 198 pp.

GLIESSMAN, S. R. (1997). Agroecology: ecological processes in sustainable agriculture. CRC Press, Boca Raton. 
Goddek, S., Delaide, B., Mankasingh, U., Ragnarsdottir, K. V., Jijakli, H. \& THORARINSDOTTIR, R. (2015). Challenges of sustainable and commercial aquaponics. Sustainability 7, 4199-4224.

GozLAN, R. E. (2017). Interference of non-native species with fisheries and aquaculture. In Impact of Biological Invasion on Ecosystems Services (eds M. Vila and P. E. Hulme), Book Series Invading Nature, Springer Series in Invasion Ecology 12, 119-137.

Gravel, D., Albouy, C. \& Thuiller, W. (2016). The meaning of functional trait composition of food webs for ecosystem functioning. Philosophical Transactions of the Royal Society B 371, 20150268.

HAO-REN, L. (1982). Polycultural system of freshwater fish in China. Canadian Journal of Fisheries and Aquatic Sciences 39, 143-150.

Henne, J. P., Romero, M. M. \& CARmichael, G. J. (2007). Polyculture of endangered bonytails and razorback suckers in recirculated water. North American Journal of Aquaculture 69, 388-394.

Hisano, H. Barbosa, P. T. L., Hayd, L.A. \& Mattioli, C. C. (2019). Evaluation of Nile tilapia in monoculture and polyculture with giant freshwater prawn in biofloc technology system and in recirculation aquaculture system. International Aquatic Research 11, 335346.

Ibrahem, M. D., Shasheed, A. B., El-YAZEed, A. E. \& KorAni, H. (2011). Assessment of the susceptibility of polyculture reared African Catfish and Nile Tilapia to Edwardsiella tarda. Journal of American Science 7, 779-786.

Isbell, F., Adler, P. R., Eisenhauer, N., Fornara, D., Kimmel, K., Kremen, C., Letourneau, D. K., Liebman, M., Polleu, H. W, Quijas, S. \& Scherer-Lorenzen, M. (2017). Benefits of increasing plant diversity in sustainable agroecosystems. Journal of Ecology 105, 871-879. 
JAEGer, C., FoucARD, P., TOCQueVILle, A., NAHON, S. \& Aubin, J. (2019). Mass balanced based LCA of a common carp-lettuce aquaponics system. Aquacultural Engineering 84, $29-41$.

Jennings, S., Stentiford, G. D., Leocadio, A. M., JefFery, K. R., Metcalfe, J. D., Katsiadaki, I., Auchterlonie, N. A., Mangi, S. C., Pinnegar, J. K., Ellis, T., Peeler, E. J., Luisetti, T., Baker-Austin, C., Brown, M., Catchpole, T. L., ET AL. (2016). Aquatic food security: insights into challenges and solutions from an analysis of interactions between fisheries, aquaculture, food safety, human health, fish and human welfare, economy and environment. Fish and Fisheries 17, 893-938.

Karim, M., Little, D. C., Shamshul Kabir, M. D., Verdegem, M. J. C., Telfer, T. \& WAHAB, M. D. A. (2011). Enhancing benefits from polycultures including Tilapia (Oreochromis niloticus) within integrated pond-dike systems: A participatory trial with households of varying socio-economic level in rural and peri-urban areas of Bangladesh. Aquaculture 314, 225-235.

Knowler, D., Chopin, T., MartineZ-EspiñeIRA, R., NeORI, A., Nobre, A., Noce, A. \& REID, G. (2020). The economics of Integrated Multi-Trophic Aquaculture: where are we now and where do we need to go? Reviews in Aquaculture 12, 1579-1594.

Konig, B., Junge, R., BitTsanszky, A., Villarroel, M. \& Komives, T. (2016). On the sustainability of aquaponics. Ecocycles 2, 26-32.

Kozlowski, M., Szczepkowski, M., Wunderlich, K., SzczepKowska, B. \& PiotrowskA, I. (2014). Polyculture of juvenile pikeperch (Sander lucioperca L.) and sterlet (Acipenser ruthenus L.) in a recirculating system. Archives of Polish Fisheries 22, 237-242.

Kumaresan, A., Pathak, K. A., Bujarbaruah, K. M. \& Vinod, K. (2009). Analysis of integrated animal-fish production system under subtropical hill agro ecosystem in India: 
Growth performance of animals, total biomass production and monetary benefit. Tropical Animal Health Production 41, 385-391.

840

841

Lazartigues, A., Banas, D., Feidt, C., Brun-Bellut, J., Gardeur, J. N., Le RouX, Y. \& THOMAS, M. (2013). Pesticide pressure and fish farming in barrage pond in northeastern France. Part III: how management can affect pesticide profiles in edible fish? Environmental Science and Pollution Research 20, 126-135.

Lecocq, T., Benard, A., Pasquet, A., Nahon, S., Ducret, A., Dupont-Marin, K., Lang, I. \& ThOmAs, M. (2019). TOFF: a database of Traits OF Fish to promote advances in fish aquaculture. Scientific Data, 6, 301.

Li, M., Callier, M. D., Blancheton, J. P., Gales, A., Nahon, S., Triplet, S., Geoffroy, T., Menniti, C., Fouilland, E. \& D’OrbCAStel, E. R. (2019). Bioremediation of fishpond effluent and production of microalgae for an oyster farm in an innovative recirculating integrated multi-trophic aquaculture system. Aquaculture 504, 314-325.

LI, Z., LiU, J., WANG, Q. \& DE Silva, S. S. (2018). Inland Aquaculture: Trends and prospects. In Aquaculture in China, Success stories and modern trends (eds J. F. GUI, Q. TANG, Z. LI, J. LiU and S. S. De SiLVA), pp. 25-36. Wiley Blackwell.

LIN, Y., GAO, Z. \& ZHAN, A. (2015). Introduction and use of non-native species for aquaculture in China: status, risks and management solutions. Reviews in Aquaculture 7, $28-58$.

LitTLE, D. C. \& EDWARDS, P. (2003). Integrated livestock-fish farming systems. Rome: Food and Agriculture Organization of the United Nations.

LIU, X., XU, H. \& LIU, C. (2018). Ecological engineering technologies for optimizing freshwater pond aquaculture. In Aquaculture in China, Success stories and modern trends (eds J. F. GuI, Q. TAng, Z. LI, J. LiU and S. S. DE SiLva), pp. 555-576. Wiley Blackwell. 
Lorenzen, K., Beveridge, M. C. M. \& MAngel, M. (2012). Cultured fish: integrative biology and management of domestication and interactions with wild fish. Biological Reviews 87, 639-660.

Love, D. C., Fr,y J. P., Genello, L., Hill, E. S., Frederick, J. A., Li, X. M. \& Semmens, K. (2014). An international survey of aquaponics practitioners. PloS One 9, e102662.

MARTINEZ-Porchas, M. \& MARTINEZ-Cordova, L. R. (2012). World aquaculture: environmental impacts and troubleshooting alternatives. The Scientific World Journal 2012, 1-9.

Martinez-Porchas, M., MartineZ-Cordova, L. R., Porchas-Cornejo, M. A. \& LoPeZELIAS, J. A. (2010). Shrimp polyculture: a potentially profitable, sustainable, but uncommon aquacultural practice. Reviews in Aquaculture 2, 73-85.

Martins, C. I. M., Eding, E. H., Verdegem, M. C. J., Heinsbroek, L. T. N., Schneider, O., Blancheton, J. P., Roque D’Orbcastel, E. \& Verreth, J. A. J. (2010). New developments in recirculating aquaculture systems in Europe: a perspective on environmental sustainability. Aquacultural Engineering 43, 83-93.

Medeiros, M. V., Aubin, J. \& CAmargo, A. F. M. (2017). Life cycle assessment of fish and prawn production: comparison of monoculture and polyculture freshwater systems in Brazil. Journal of Cleaner Production 156, 528-537.

Meng, L., Callier, M. D., Blancheton, J. P., Gales, A., Nahon, S., Triplet, S., Geoffroy, T., Menniti, C., Fouilland, E. \& D'OrbCastel, E. R. (2019). Bioremediation of fishpond effluent and production of microalgae for an oyster farm in an innovative recirculating integrated multi-trophic aquaculture system. Aquaculture 504, $314-325$.

MiLSTEIN, A. (1992). Ecological aspects of fish species interactions in polyculture ponds. Hydrobiologia 231, 177-186. 
Milstein, A. (2005). Polyculture in aquaculture. Animal Breeding Abstracts 73, 15N-41N.

Milstein, A., Ahmed, A. F., Masud, O. A., Kadir, A. \& WaHAB, M. A. (2006). Effects of the filter feeder silver carp and the bottom feeders mrigal and common carp on small indigenous fish species (SIS) and pond ecology. Aquaculture 258, 439-451.

Mungkung, R., Aubin, J., Prihadi, T. H., Slembrouck, J., VAn Der Werf, H. M. G. \& LEGENDRE, M. (2013). Life cycle assessment for environmentally sustainable aquaculture management: a case study of combined aquaculture systems for carp and tilapia. Journal of Cleaner Production 57, 249-256.

NAYLOR, R., WiLliams, S. \& STRONG, D. (2001). Aquaculture - A gateway for exotic species. Science 294, 1655-1656.

Naylor, R. L., Hardy, R. W., Bureau, D. P., Chiu, A., Elliott, M., Farrell, A. P., Forster, I., Gatlin, D. M., Goldburg, R. J., HuA, K. \& Nichols, P. D. (2009). Feeding aquaculture in an era of finite resources. Proceedings of the National Academy of Sciences 106, 15103-15110.

Nelson, E. J., MacDonald, B. A. \& Robinson, S. M. C. (2012). The absorption efficiency of the suspension-feeding sea cucumber, Cucumaria frondosa, and its potential as an extractive integrated multi-trophic aquaculture (IMTA) species. Aquaculture 370-371, 19 25.

Neori, A., Chopin, T., Troell, M., Buschmann, A. H., Kraemer, G. P., Halling, C., SHPIGEL, M. \& YARISH, C. (2004). Integrated aquaculture: rationale, evolution and state of the art emphasizing seaweed biofiltration in modern mariculture. Aquaculture 231, 361391.

Nhan, D. K., Milstein, A., Verdegem, M. C. J. \& Verreth, J. A. V. (2006). Food inputs, water quality and nutrient accumulation in integrated pond systems: a multivariate approach. Aquaculture 261, 160-173. 
Nhan, D. K., Phong, L. T., Verdegem, M. J. C., Duong, L. T., Bosma, R. H. \& Little, D. C. (2007). Integrated freshwater aquaculture, crop and livestock production in the Mekong delta, Vietnam: determinants and the role of the pond. Agricultural Systems 94, 445-458.

Noss, R. F. (1990). Indicators for monitoring biodiversity: A hierarchical approach. Conservation Biology 4, 355-364.

Pant, J., Demaine, H. \& Edwards, P. (2004). Assessment of the aquaculture subsystem in integrated agriculture-aquaculture systems in Northeast Thailand. Aquaculture Research 35, 289-298.

Papoutsoglou S. E., Miliou, H., Karakatsouli N. P., Tzitzinakis M. \& Chadio S. (2001). Growth and physiological changes in scaled carp and blue tilapia under behavioral stress in mono- and polyculture rearing using a recirculated water system. Aquaculture International 9, 509-518.

Pey, B., Nahmani, J., Auclerc, A., Capowiez, Y., Cluzeau, D., Cortet, J., Decä̈ns, T., Deharveng, L., Dubs, F., Joimel, S., Briard, C., Grumiaux, F., Laporte, M. A., Pasquet, A., Pelosi, C., ET AL. (2014). Current use of and future needs for soil invertebrate functional traits in community ecology. Basic and Applied Ecology 15, 194 206.

PREIN, M. (2002). Integration of aquaculture into crop-animal systems in Asia. Agricultural Systems 71, 127-146.

Rahman, M. M., Nagelkerke, L. A. J., Verdegem, M. C. J., Wahab, M. A. \& Verreth, J. A. J. (2008). Relationships among water quality, food resources, fish diet and fish growth in polyculture ponds: a multivariate approach. Aquaculture 275, 108-115.

Rahman, M. M., Verdegem, M. C. J., Nagelkerke, L. A. J., Wahab, M. A., Milstein, A. \& VERRETH, J. A. J. (2006). Growth, production and food preference of rohu Labeo rohita 
(H.) in monoculture and in polyculture with common carp Cyprinus carpio (L.) under fed and non-fed ponds. Aquaculture 257, 359-372.

938

939

RAKOCY, J. E. (1989). Vegetable hydroponics and fish culture, a productive interface. World Aquaculture 20, 42-47.

Rawson, M. V., Chen, C. S., Ji, R. B., Zhu, M. Y., WAnG, D. R., WANG, L., YARIsh, C., Sullivan, J. B., CHOPIN, T. \& CARMONA, R. (2002). Understanding the interaction of extractive and fed aquaculture using ecosystem modelling. In Responsible Marine Aquaculture (eds R. R. Stickney and J. P. McVey), pp. 263-296. Conference on Aquaculture Sustainability, Orlando, FL, 2001.

Reid, G. K., Gurney-Smith, H. J., Flaherty, M., GARber, A. F., Forster, I., BrewerDalton, K., Knowler, D., Marcogliese, D. J., Chopin, T., Moccia, R. D., Smith, C. T. \& DE SILVA, S. (2019). Climate change and aquaculture: considering adaptation potential. Aquaculture Environment Interactions 11, 603-624.

Ren, J. S., Stenton-Dozey, J., Plew, D. R., Fang, J. \& Gall, M. (2012). An ecosystem model for optimising production in integrated multitrophic aquaculture systems. Ecological Modelling 246, 34-46.

Robertson, G. P. \& Swinton, S. M. (2005). Reconciling agricultural productivity and environmental integrity: a great challenge for agriculture. Frontiers in Ecology and the Environment 3, 38-46.

Sabatier, R., Durant, D., Hazard, L., Lauvie, A., Lecrivain, E., Magda, D., Martel, G., Roche, B., De Sainte Marie, C., Teillard, F. \& Tichit, M. (2015). Towards biodiversity-based livestock systems: review of evidence and options for improvement. CAB Review 10, 1-13.

SANDIFER, P. A. \& Hopkins, S. J. (1996). Conceptual design of a sustainable Pond-based shrimp culture system. Aquacultural Engineering 15, 41-52. 
Saraiva, J. L., Arechavala-Lopez, P., Castanheira, M. F., Volstorf, J. \& Studer, B. H. (2019). A global assessment of welfare in farmed fishes: the FishEthoBase. Fishes 4, 30.

Shoko, A. P., Limbu, S. M., Mrosso, H. D. J., Mkenda, A. F. \& Mgaya, Y. D. (2016). Effect of stocking on growth, production and economic benefits of mixed sex Nile tilapia (Oreochromis niloticus) and African sharptooth catfish (Clarias gariepinus) in polyculture and monoculture. Aquaculture Research 47, 36-50.

Silknetter, S., Creed, R. P., Brown, B. L., Frimpong, E. A., Skelton, J. \& Peoples, B. K. (2020). Positive biotic interactions in freshwaters: a review and research directive. Freshwater Biology 65, 811-832.

SONAY, D. F. \& BASCINAR, N. (2017). An investigation on the effects of juvenile rainbow trout (Oncorhynchus mykiss) and brook trout (Salvelinus fontinalis) monoculture and duoculture farming in freshwater and seawater on growth performance. Iranian Journal of Fisheries Sciences, 16, 38-49.

Stickney, R. R. (2013). Polyculture in Aquaculture. In Sustainable Food Production (eds P. Christou, R. Savin, B. A. Costa-Pierce, I. Misztal and C. B. A. Whitelaw), pp. 1366-1368. Springer, New York.

SwifT, M. J., IZAC, A. M. \& VAN NOORDWIJK, M. (2004). Biodiversity and ecosystem services in agricultural landscapes: are we asking the right questions? Agriculture, Ecosystems and Environment 104, 113-134.

Tacon, A. G. J., Metian, M., Turchini, G. M. \& De Silva, S. S. (2010). Responsible aquaculture and trophic level implications to global fish supply. Reviews in Fisheries Science 18, 94-105. 
Tendencia, E. A., Fermin, A. C., Dela Pena, M. R. \& Choresca Jr. C. H. (2006). Effect of Epinephelus coioides, Chanos chanos, and GIFT tilapia in polyculture with Penaeus monodon on the growth of the luminous bacteria Vibrio arveyi. Aquaculture 253, 48-56.

Thomas, M., Lecocq, T., Abregal, C., Nahon, S., Aubin, J., Jaeger, C., Wilfart, A., SchaefFer, L., Ledoré, Y, Puillet, L. \& PAsquet, A. (2020). The effects of polyculture on behaviour and production of pikeperch in recirculation systems. Aquaculture Reports 17, 100333.

Thomas, M., Mairesse, G., Gardeur, J.N. \& Brun-Bellut, J. (2015). Concept and determinism of quality in Percid Fishes. In Biology and Culture of Percid Fishes Principles and Practice (eds P. KeStemont, K. DABROWSKI and R. C. SUMMERFELS), pp. 843-864. Springer.

Tian, X. L., LI, D. S., Dong, S. L., YAn, X. Z., QI, Z. X., LiU, G. C. \& LU, J. (2001). An experimental study on closed-polyculture of penaeid shrimp with tilapia and constricted tagelus. Aquaculture 202, 57-71.

TOOMEY, L., FontAine, P. \& LECOCQ, T. (2020). Unlocking the intraspecific aquaculture potential from the wild biodiversity to facilitate aquaculture development. Reviews in Aquaculture. in press. DOI:10.1111/raq.12430

Troell, M., Joyce, A., Chopin, T., Neori, A., Buschmann, A. H. \& Fang, J.-G. (2009). Ecological engineering in aquaculture - Potential for integrated multi-trophic aquaculture (IMTA) in marine offshore systems. Aquaculture 297, 1-9.

Tyson, R. V., Treadwell, D. D. \& Simonne, E. H. (2011). Opportunities and challenges to sustainability in aquaponic systems. Horttechnology 21, 6-13.

Valenti, W. C., Kimpara, J. M., DE L. Preto, B. \& Moraes-VAlenti, P. (2018). Indicators of sustainability to assess aquaculture systems. Ecological Indicators 88, 402-413. 
Vaughan, D. B., Grutter, A. S. \& Hutson, K. S. (2018). Cleaner shrimp are a sustainable option to treat parasitic disease in farmed fish. Scientific Reports 8, 13959.

Villarroel, M., Junge, R., Komives T., KÖnig, B., Plaza, I., BittsánszKy, A. \& Joly, A. (2016). Survey of Aquaponics in Europe. Water 8, 468.

Violle, C., Enquist, B. J., McGill, B. J., Jiang, L., Albert, C. H., Hulshof, C., Jung, V. \& MESSIER, J. (2012). The return of the variance: intraspecific variability in community ecology. Trends in Ecology and Evolution 27,244-252.

Violle, C., Navas, M. L., Vile, D., KaZakou, E., Fortunel, C., Hummel, I. \& Garnier, E. (2007). Let the concept of trait be functional! Oikos 116, 882-892.

Volaire, F., BARKAOUI, K. \& Norton, M. (2014). Designing resilient and sustainable grasslands for a drier future: adaptive strategies, functional traits and biotic interactions. European Journal of Agronomy 52, 81-89.

Walker, B., Holling, C. S., CARPenter, S. R. \& KinZig, A. (2004). Resilience, adaptability and transformability in social-ecological systems. Ecology and Society $\mathbf{9}, 5$.

WAnG, J. Q., LI, D. S., Dong, S. L., WANG, K. X. \& Tian, X. L. (1998). Experimental studies on polyculture in closed shrimp ponds - I. Intensive polyculture of Chinese shrimp (Penaeus chinensis) with tilapia hybrids. Aquaculture 163, 11-27.

WAng, Q., Cheng, L., LiU, J., Li, Z., XIE, S. \& De Silva, S. S. (2015). Freshwater aquaculture in PR China: trends and prospects. Reviews in Aquaculture 7, 283-312.

Willot, P.-A., Aubin, J., SAlles, J.-M. \& Wilfart, A. (2019). Ecosystem service framework and typology for an ecosystem approach to aquaculture. Aquaculture 512, 734260.

WCED (World Commission on the Environment and Development) (1987). Our Common Future. Oxford University Press, New York, USA. 
Wood, S. A., Karp, D. S., DeClerck, F., Kremen, C., Naeem, S. \& Palm, C. A. (2015). Functional traits in agriculture: agrobiodiversity and ecosystem services. Trends in Ecology and Evolution 30, 531-539.

XIE, C., Li, J., LI, D., Shen, Y., GAO, Y. \& Zhang, Z. (2018). Grass carp: the fish that feeds half of China. In Aquaculture in China, Success stories and modern trends (eds J. F. GUI, Q. TANG, Z. LI, J. LIU and S. S. DE SILVA), pp. 95-115. Wiley Blackwell.

ZAJdBAnd, A. D. (2011). Integrated Agri-Aquaculture Systems. In Genetics, Biofuels and Local Farming Systems (eds E. LiCHTFOUSE), pp. 87-127. Dordrecht, the Netherlands, Springer Science.

ZHAO, S. (1994). Geography of China: Environment, Resources, Population and Development. John Wiley and Sons, New York, pp. 332.

Zhou, B., Dong, S. \& WANG, F. (2015). Trophic structure and energy fluxes in a grass carp (Ctenopharyngodon idellus) cultured pond ecosystem. Aquaculture International 23, $1313-1324$. 
Fig. 1. Illustration of polyculture involving basic complementarity. (A) Multitrophic aquaculture with unfed species using different trophic resources available in the farm environment, for example in pond systems (e.g. traditional Chinese polyculture of carp). Figure adapted from Milstein (2005) and Dumont et al. (2020). The species are complementary in their use of trophic resources due to their different diets and/or trophic plasticity. (B) Monotrophic aquaculture with two fed species using the same trophic resource (e.g. pellets), for example in cages or recirculating aquaculture systems. These species are complementary in their use of spatial resources in the rearing environment, with one species feeding in the water column, while the second feeds on the bottom (Kozlowski et al., 2014; Thomas et al., 2020).
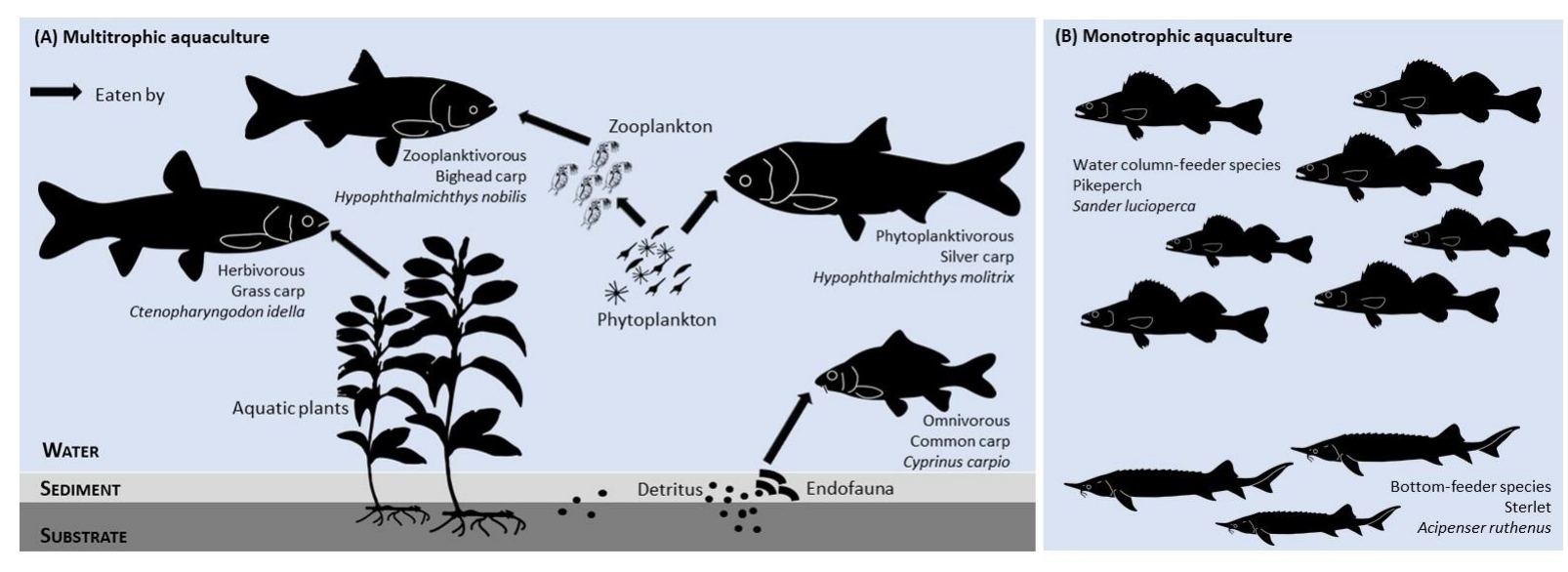

(1)

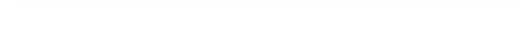


1059

1060

1061

1062

1063

1064

1065

1066

1067

1068

1069

1070

1071

1072

1073
Fig. 2. Illustration of polyculture based on enhanced complementarity through trophic interactions among species. (A) Polyculture based on integrated multi-trophic aquaculture in which water flows support trophic interactions. The principle is based on waste from one production subsystem serving as a food resource for another. Thus, pellet-fed finfish species are reared in cages. Faeces and uneaten food deposit under the cages and are consumed by detritivorous species (e.g. sea cucumber). Particulate and dissolved organic matter is used by extractive species (e.g. shellfish, seaweed) reared near the cages. Figure adapted from Chopin et al. (2010). (B) Polyculture based on integrated agriculture-aquaculture that connects terrestrial and aquatic production units (Prein, 2002; Dumont et al., 2013). Nutrient recycling is organised between farm components: crop co-products feed livestock (e.g. ruminants, poultry or pigs) and fertilise the aquatic environment (e.g. pond). Livestock manure fertilises crops and the aquatic system. Pond sediments fertilise crops, while livestock consume aquatic plants (macrophytes). The aquatic system is also a water source for the terrestrial production unit.

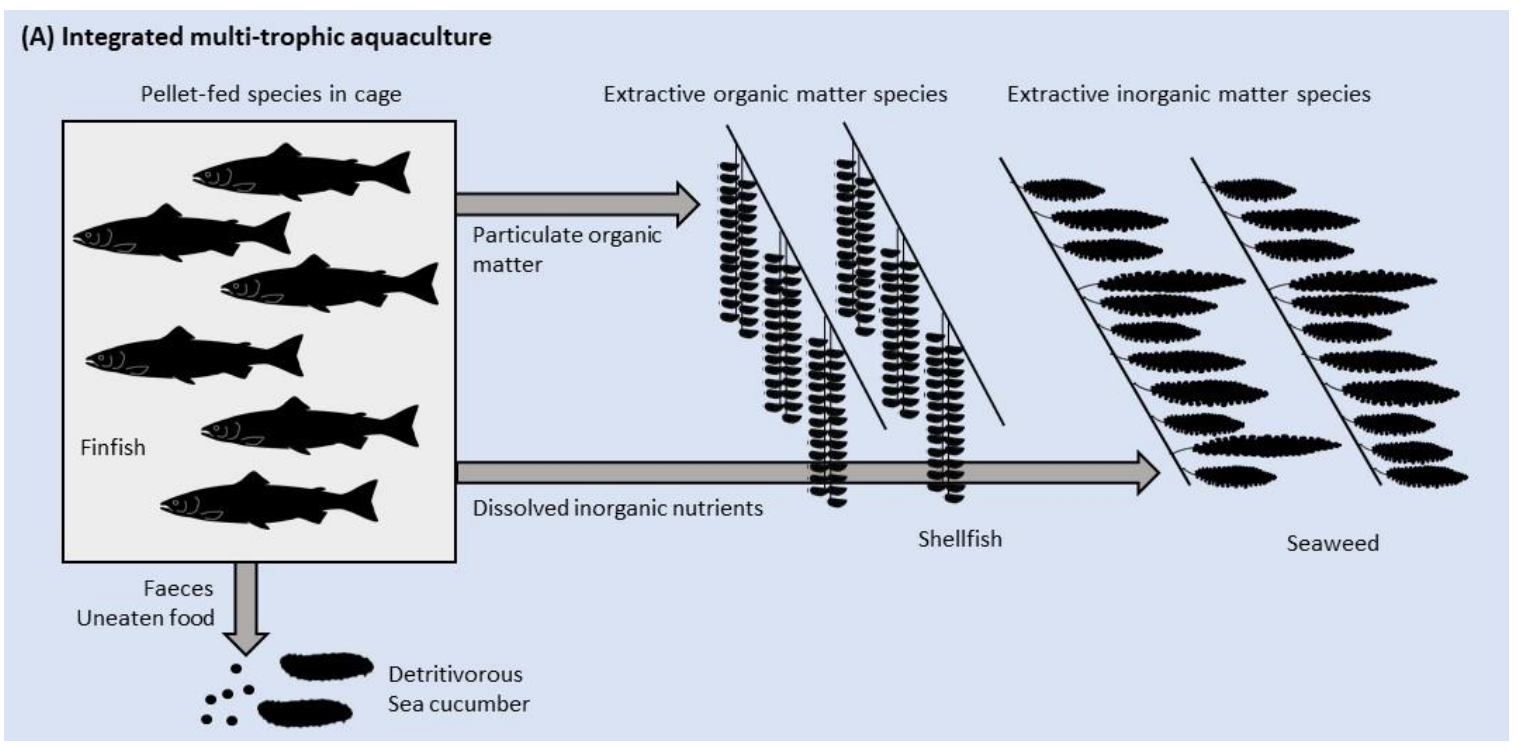




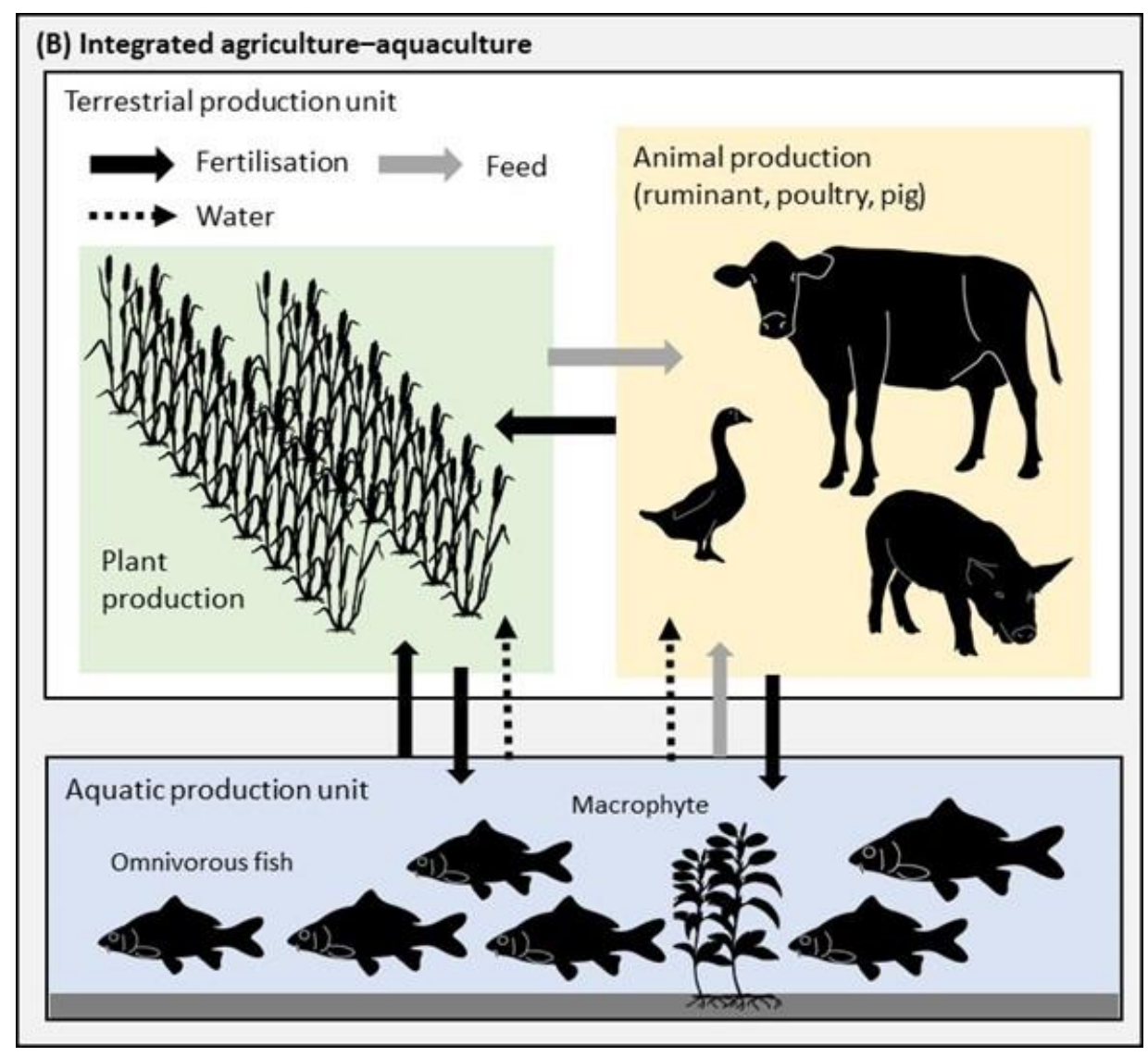

1075 
1076 Fig. 3. Illustration of polyculture based on enhanced complementarity via beneficial

1077 interactions among species. (A) Polyculture based on commensalism between finfish. The

1078 foraging behaviour of one species improves resource availability for another species by

1079 resuspending nutrients accumulated in the sediment into the water column. Figure adapted

1080 from Milstein (2005) and Dumont et al. (2020). This bottom-up control illustrates facilitation

1081 in the pond. (B) Polyculture based on mutualism between finfish. The two species benefit

1082 from being reared together, for example in cages. Here, a 'client' species is freed of

1083 ectoparasites by a 'cleaner' species, which feeds on them (Brooker et al., 2018).
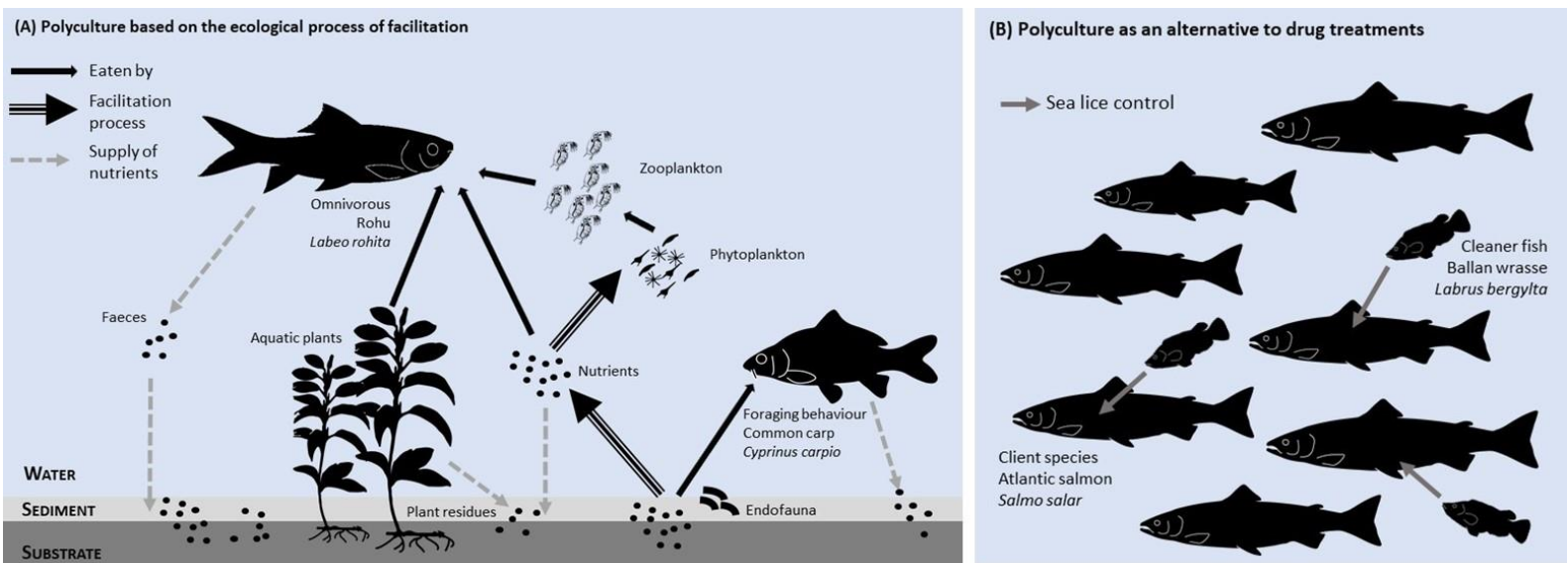
Fig. 4. The four-step conceptual framework for designing innovative polyculture systems.

Step 1 defines the relevant species combination based on species compatibility and complementarity concepts and a prospective approach based on species functional traits. Step 2 selects the appropriate farming system using an integrated approach in order to consider relationships among all compartments in space and time, as well as practices that can influence functional processes. Step 3 defines the strategy to manage the complexity of the polyculture system using specific tools and system evaluation indicators. Step 4, which is simultaneous, focuses on implementing polyculture design in aquaculture by considering stakeholders' expectations and advice. Ultimately, the approach provides a relevant polyculture design for a particular production system as well as a management strategy.

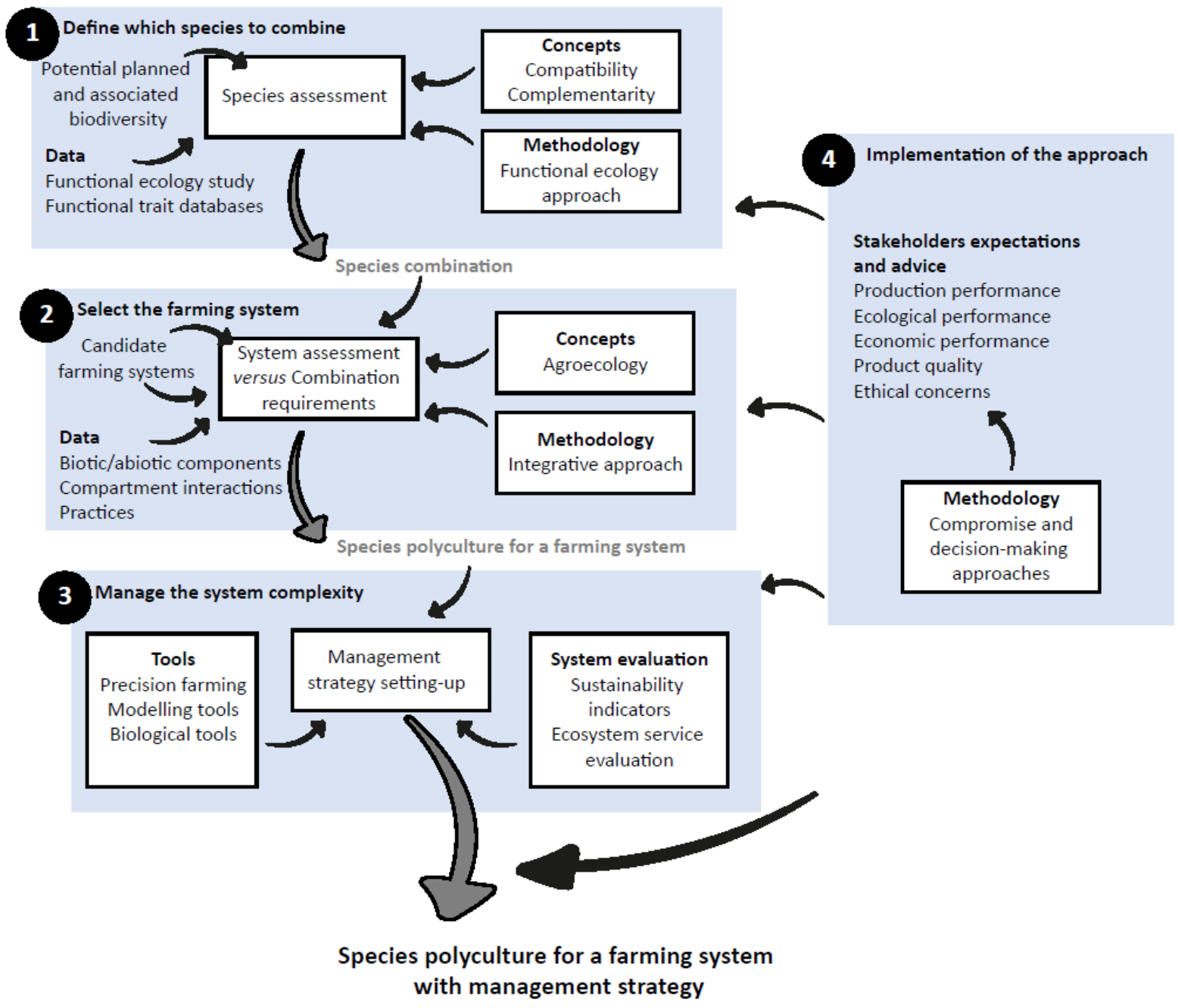


Table 1. Definitions of terms used in this review.

\begin{tabular}{ll}
\hline Term & Definition \\
\hline Agroecology & An integrative approach that considers ecological processes when designing and managing sustainable \\
& agro-ecosystems with minimal external inputs due to system-specific processes and resources
\end{tabular}

agro-ecosystems with minimal external inputs due to system-specific processes and resources

References

Adapted from Altieri

(1987); Dumont et al.

(2013); Gliessman

(1997)

Aquaculture

Aquaponics

Biodiversity

Commensalism

Facilitation

Functional trait

Integrated agriculture-

aquaculture (IAA)

Integrated multi-trophic aquaculture (IMTA)
The cultivation of aquatic organisms in freshwater, brackish, or marine water, under controlled conditions. Note: we excluded pet aquaculture from this study.

Integrated multi-trophic aquaculture that cycles wastewater from animals reared in an aquaculture unit to plants grown in a hydroponic unit

Diversity that encompasses all levels of biological organisation and ecological functions

Interaction in which one species benefits while the other has no net cost or benefit

Type of commensalism in which one species improves resource availability for another species

A morphological, physiological, phenological, or behavioural characteristic measurable in individual organisms that influences their fitness (i.e. ability to survive and reproduce) directly or indirectly

A polyculture approach that combines two or more agricultural activities, at least one of which is aquaculture, on the basis of mass, material, and/or energy flows

A polyculture approach that combines functional groups of species that are connected to each other via water flows that contain trophic sources, with the waste from one species serving as a food for other species

Obligate or facultative interactions in which both species involved receive a measurable net benefit
Adapted from Rakocy

(1989)

Adapted from Noss (1990)

Silknetter et al. (2020)

Adapted from Arsenault \& Owen-Smith (2002)

Adapted from Pey et al.

(2014); Violle et al.

(2012); Wood et al.

Adapted from Little \& Edwards (2003); Prein (2002)

Adapted from Chopin et al. (2008); Neori et al. (2004); Meng et al.

(2019); Bostock et al.

Silknetter et al. (2020) 
Polyculture

Raceway

Recirculated aquaculture system (RAS)

Resilience

Species diversity

Species compatibility

Species complementarity

Sustainability

Welfare
Rearing/breeding two or more species (aquatic species only or aquatic and terrestrial species) in a particular production system (e.g. pond) at the same time

Adapted from Stickney

A rearing system that consists of an artificial channel fed by a continuous flow of water for intensive fish rearing

An intensive rearing system with aquatic animals (usually fish) that provides a constant and controlled environment, with a water treatment unit that maintains adequate water quality and restricts the supply of new water

A system's capacity to absorb disturbances and reorganise to maintain functioning after undergoing changes

The number of species combined in the same production system

The ability of species to live in the same production system without detrimental interactions (e.g. parasitism, predation) or competition for resources (e.g. food, space, shelter)

The ability of species to $(i)$ use different portions of available resources (including by-products of other co-farmed species), or (ii) display commensal/mutualistic interactions that increase sustainability of the production system

The ability to meet environmental, social, and economic human needs of the present without compromising the ability of future human generations to meet their needs

The physical and mental state of individuals living without stress (i.e. an event that results in disturbances to homeostasis) in a production unit in which international ethical regulations are applied
Walker et al. (2004)

Present study

Present study

Adapted from WCED

Present study 
Table 2. Case studies that illustrate how polyculture can increase environmental sustainability and socio-economic sustainability, classified into two categories: (i) basic complementarity, in which a species combination exploits different available resources; and (ii) enhanced complementarity, in which species use co-products of other taxa [integrated multi-trophic aquaculture (IMTA); integrated agricultureaquaculture (IAA)] and/or benefit from commensalism or mutualism. RAS, recirculated aquaculture system. Environmental sustainability is indicated in bold and socio-economic sustainability is in italics.

\begin{tabular}{llll}
\hline Polyculture case study & Consequences for sustainability & Processes involved & References \\
\hline BASIC COMPLEMENTARITY & &
\end{tabular}

Bonytails (Gila elegans) and razorback suckers (Xyrauchen texanus) reared in a RAS

Pikeperch (Sander lucioperca) and sterlet (Acipenser ruthenus) reared in a RAS

Combination of pikeperch (Sander lucioperca) with sterlet (Acipenser ruthenus) or with sterlet and tench (Tinca tinca) in a RAS

Fish polyculture in two or more layered cages, generally with a highvalue species (e.g. sturgeon Acipenser sp.) in the most internal cages and cyprinids [e.g. bighead carp (Hypophthalmichthys nobilis), silver carp (Hypophthalmichthys molitrix), crucian carp (Carassius auratus)] in the most external cages
- Decrease in labour in polyculture compared to that in monoculture of $G$. elegans: percentage of working time spent manually removing solid waste decreased from $5.6 \%$ to $3.5 \%$

- Decrease in labour in polyculture compared to that in monoculture of $S$. lucioperca: weekly versus daily removal of unconsumed feed, respectively

- Improvement in production performance: an increase in pikeperch mass from $25 \%$ in monoculture to $51 \%$ in polyculture

\section{- Preservation of water quality}

- Decrease in the risk of fish escaping
Use of the benthic behaviour of $X$. texanus.

Henne et al. (2007)

Consumption and resuspension of solid waste in

the water column, which helps it leave the system instead of accumulating on the bottom of the basin

Use of the benthic trophic behaviour of $A$.

ruthenus, which consumes food that

accumulates on the bottom of the basin

Combination of fish species with the same water-quality requirements that exploit different spatial resources (decrease in competition among fish for trophic resources)

Fish in the most external cages consume uneaten food distributed to species in the most internal

Kozlowski et al.

Thomas et al.

(2020) cages 
Introduction of ornamental fish (seahorse) culture to shrimp/oyster farms
- A supplemental income source from seahorse production

- An alternative to wild catch: reduced pressure on seahorse populations and habitat disturbance
Combination of three species with the same

Fonseca et al. water-quality requirements that exploit different

trophic resources (shrimp: benthic and detritivorous species; oyster: close to the water surface and phytoplanktivorous; fish: in cages and zooplanktivorous)

\section{ENHANCED COMPLEMENTARITY}

IMTA: method of rearing shrimp (Penaeus vannamei or Penaeus setiferus) combined with herbivorous mullets (Mugil cephalus) and oysters (Crassostrea virginica).

IMTA: combination of pellet-fed species (e.g. fish or shrimp) with species that extract particulate or dissolved organic matter (e.g. fish, echinoderms, molluscs) and species that extract inorganic matter (e.g. micro- and macro-algae, macrophytes)

IMTA: semi-intensive tilapia (Oreochromis niloticus) and prawn (Macrobrachium amazonicum) IMTA systems

IMTA: addition of an iliophagus fish species (Prochilodus lineatus) to the integrated culture of pelagic fish (Colossoma macropomum) and benthic prawns (Macrobrachium amazonicum

\section{- Recycling of water}

- Use of co-products: mullets and oysters feed on the wastewater from cultured shrimp, thus acting as filter feeders

- Production of additional products

\section{- Preservation of water quality}

- Improvement in nutrient cycling within culture units and diversification of production: $50 \%$ of nitrogen supplied to the system was converted into marketable biomass in pond polyculture or IMTA compared to $25-35 \%$ in traditional aquaculture systems

\section{- Improvement in nutrient cycling in earthen} ponds and diversification of production: up to $28 \%$ of phosphorus supplied to the system was converted into harvestable products

- Improvement in nutrient cycling within ponds: transformation of waste into valuable biomass

- Diversification of and improvement to production: total species yields increased by approximately $35 \%$ and feed conversion ratio decreased by approximately $31 \%$
Combination of aquatic species with

complementary dietary needs and behaviours

Sandifer \& Hopkins (1996)

Combination of several functional groups of species

Martinez-Porchas \& Martinez-

Cordova (2012);

Meng et al. (2019)

Combination of several functional groups of species that use co-products for feed

David et al. $(2017 b)$

Combination of fed species with two species that feed on the uneaten diet and waste of the fed anchini et al. 
IMTA: integrated system with shellfish (Haliotis discus hannai), sea cucumber (Apostichopus japonicas) and fish (Sebastes schlegeli) reared in a RAS system

IMTA: combination of plants [e.g. water convolvulus (Ipomea aquatica), water lettuce (Pistia spp.), water hyacinth (Eichhornia crassipes)] and cultured fish (e.g. grass carp

Ctenopharyngodon idella) or shellfish

IAA: use of livestock manure and other agricultural wastes to fertilise fishponds; use of pond sediments to fertilise crops and crop by-products to feed livestock and fish

IAA: integrated production of freshwater prawn (Macrobrachium rosenbergii) and rice (Oryza sativa)

Commensalism: combination of rohu (Labeo rohita) and carp (Cyprinus carpio) in a pond

Commensalism: polyculture of white shrimp (Litopenaeus vannamei) and an omnivorous fish (Takifugu obscurus)
- Improvement in nutrient cycling: shellfish-sea cucumber polyculture improved $\mathrm{N}$ - and $\mathrm{P}$-use rates in the system

- Diversification of and improvement in production: polyculture of shellfish and sea cucumbers increased the growth rate of shellfish compared to that of monoculture

- Improvement in water quality: plants can remove up to $52-59 \%$ of total nitrogen and $39-69 \%$ of total phosphorus, and decrease chemical oxygen demand by $17-35 \%$.

- Increase in fish production: production of grass carp and the survival rate of its fry increased by $20 \%$ and $3 \%$, respectively, while the amount of drugs used decreased by $40 \%$ compared to conventional

systems that do not include plants

- Production of additional products, such as plants that can be consumed directly by humans

- Recycling of nutrients between terrestrial and aquatic compartments of the farm, either directly or indirectly

- Increase in aquaculture and livestock yields

- Diversification of production and economic interest the gross revenue in the simultaneous rice-prawn system $\left(2\right.$ prawn $\left.\mathrm{m}^{-2}\right)$ was 2.5 -fold that in rice monoculture

- Increase in productivity: $40 \%$ more rohu produced in polyculture than in rohu monoculture and nearly twice the amount of pond production

- Increase in productivity due to better health conditions: improvement in shrimp resistance and/or protection against diseases when shrimp are associated with fish farms. Shrimp survival rates are
Polyculture of species with different ecological niches and different feeding habits: pellet-fed organisms with deposit-feeding organisms

Gao et al. (2019)

Water purification by plants, which take up

Liu et al. (2018); nutrients released into the water from cultured fish or shellfish units

Microorganisms on plant roots decompose and use organic pollutants and excess dissolved nutrients (nitrogen, phosphate), and plants provide habitats for animal species

Combination of several functional species groups

Karim et al. (2011) Kumaresan et al. (2009); Edwards

A multi-spatial system that uses soil and water more efficiently than a monoculture system

Boock et al. (2016)

Facilitation process: resuspension of nutrients due to the burrowing behaviour of carp

Rahman et al

(2006)

Use of the antibacterial, antifungal and cytotoxic properties of fish mucus

Jang et al. (2007) cited by Dey et al. (2020); Tendencia et al. (2006) 
less than $20 \%$ in monoculture but greater than $30 \%$

in polyculture

Commensalism: polyculture of white shrimp (Litopenaeus vannamei) with grey mullet (Mugil cephalus)

Mutualism: polyculture of cleaner shrimp (Lysmata vittata) and

(Epinephelus coioides)
- Improvement in water quality and thus in farm performance: the incidence and abundance of opportunistic parasites decreased in polyculture compared to that in monoculture due to a decrease in total organic matter in the water and sediments

- Preservation of the environment: this species combination is a sustainable alternative to chemical treatments to treat fish ectoparasites

- Diversification of production and economic interest the cleaner shrimp is a valued species for the

ornamental market and feeds on several life stages of fish parasites
Use of species that improve farm environment quality through their feeding behaviour and diet

Aghuzbeni et al.

Use of species with natural predatory behaviour towards parasites and other pathogens, as an

Vaughan et al. 